
Linköping Studies in Science and Technology

Dissertation No. 2117

\title{
Synthesis and Characterization of Transition Metal Diborides
}

\author{
Jimmy Thörnberg
}

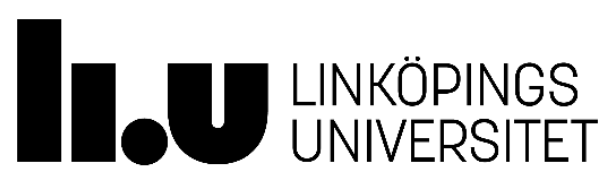

\author{
Materials Design \\ Thin Film Physics Division \\ Department of Physics, Chemistry and Biology (IFM) \\ Linköpings universitet, SE-581 83 Linköping, Sweden \\ Linköping 2021
}


Cover images: HAADF-HRSTEM of the transition-metal diboride $\mathrm{TiB}_{1.43}$ with planar defects presented as Ti-rich stacking faults (higher contrast) in nanocolumnar structures. This was the first confirmation of how B deficiency is presented in understoichiometric transition-metal diborides.

(co)EY-No This work is licensed under a Creative Commons AttributionNonCommercial 4.0 International License.

https://creativecommons.org/licenses/by-nc/4.0/

(C) Jimmy Thörnberg, 2021

Articles have been reprinted with permission of the respective copyright holders, Elsevier (Papers I and V).

ISSN: 0345-7524

ISBN: 978-91-7929-714-5

Printed in Sweden by LiU-Tryck, Linköping, 2021. 


\section{ABSTRACT}

This thesis is devoted towards physical vapor deposition (PVD) of thin films of transition-metal (TM) diborides, focused on the material system $\mathrm{TiB}_{\mathrm{x}}, \mathrm{Ti}_{1-\mathrm{x}} \mathrm{Al}_{\mathrm{x}} \mathrm{B}_{2-\mathrm{y}}$ and $\mathrm{CrB}_{\mathrm{x}}$. The metal diborides are a large family of compounds with both metallic and ceramic properties, due to its bonding nature being a mix of covalent and ionic bonds. Their characteristics include, e.g., good mechanical, electrical and thermal properties, while an improved oxidation and corrosion resistance are currently sought after. Furthermore, while the ideal composition of these diborides is $\mathrm{TMB}_{2}$, i.e. with a $\mathrm{B}$ to metal ratio of 2, the stoichiometry in the PVD deposited films typically diverges from this ratio. $\mathrm{TiB}_{\mathrm{x}}$ is often reported to be overstoichiometric, with $x$ well above 2 . One of the most known and commonly used member of the TM diboride family is $\mathrm{TiB}_{\mathrm{x}}$, primarily used in hard-coating applications such as tools for machining Al. However, the material displays a fracture toughness and oxidation resistance that ideally needs to be improved.

The films presented in this thesis were deposited by high power impulse magnetron sputtering (HiPIMS) and direct current magnetron sputtering (DCMS). Using both methods facilitates an improved control of both microstructure and composition, and hence the materials properties. With HiPIMS, understoichiometric $\mathrm{TiB}_{\mathrm{x}}$ films were grown and it was shown that these films can match and even exceed the overstoichiometric counterpart, deposited with DCMS, in terms of mechanical properties. The hardness and fracture toughness for $\mathrm{TiB}_{1.43}$ films were measured at 43.9 $\pm 0.9 \mathrm{GPa}$ and 4.2 $\pm 0.1 \mathrm{MPa} \sqrt{\mathrm{m}}$, compared to $\mathrm{TiB}_{2.70}$ films at $37.7 \pm 0.8 \mathrm{GPa}$ and $3.1 \pm 0.1 \mathrm{MPa} \sqrt{ } \mathrm{m}$. Furthermore, the understoichiometric films significantly improve the oxidation resistance. Air annealing of $\mathrm{TiB}_{1.43}, \mathrm{TiB}_{2.20}$, and $\mathrm{TiB}_{2.70}$ films at $400{ }^{\circ} \mathrm{C}$ showed an average oxidation rate of $2.9 \pm 1.5,7.1 \pm 1.0$, and $20.0 \pm 5.0 \mathrm{~nm} / \mathrm{h}$, respectively, explained by the microstructural difference between over- and understoichiometric material. In $\mathrm{TiB}_{\mathrm{x}}$ films where $x>2$, there is a B-rich tissue phase in the grain boundaries which is suggested to enhance oxidation. The hydroscopic nature of $\mathrm{B}_{2} \mathrm{O}_{3}$ causes more rapid oxidation and evaporation thus providing an easy oxidation pathway in B-rich 
regions. However, understoichiometric films where $x<2$ do not show any significant boundary phases. Instead, the B deficiency is presented as planar defects with Ti-rich stacking faults. Hence the absence of the B-rich tissue phase has strongly contributed to increasing the oxidation resistance.

Oxidation resistance and mechanical properties were also investigated for understoichiometric $\mathrm{Ti}_{1-\mathrm{x}} \mathrm{Al}_{\mathrm{x}} \mathrm{B}_{2-\mathrm{y}}$ coatings with varying Ti:Al and $\mathrm{B}: \mathrm{M}$ ratios, obtained from both HiPIMS and DCMS depositions. Al alloying of the TM diboride $\mathrm{TiB}_{\mathrm{x}}$ significantly enhances the oxidation resistance. However, incorporating too much $\mathrm{Al}$ is at the expense of the excellent hardness seen in the pure $\mathrm{TiB}_{x}$, going from $46.2 \pm 1.1 \mathrm{GPa}$ to 22.6 $\pm 1.1 \mathrm{GPa}$ for $\mathrm{Ti}_{0.9} \mathrm{Al}_{0.1} \mathrm{~B}_{1.3}$ and $\mathrm{Ti}_{0.3} \mathrm{Al}_{0.7} \mathrm{~B}_{1.3}$, respectively. Hence, a reduction in the $\mathrm{Al}$ content is needed to retain the mechanical properties. The boundary phase in this material consists of a $\mathrm{Ti}_{1-\mathrm{x}} \mathrm{Al}_{\mathrm{x}} \mathrm{B}_{2-\mathrm{y}}$ tissue phase, rich in either $\mathrm{Al}$ or $\mathrm{B}$ depending on the $x$ and $y$ values. An improved oxidation resistance in $\mathrm{Ti}_{1-\mathrm{x}} \mathrm{Al}_{\mathrm{x}} \mathrm{B}_{2-\mathrm{y}}$ was seen with reduced $\mathrm{Al}$ and $\mathrm{B}$ content, proposed to be due to absence of tissue phase in the grain boundaries, in line with the observations for $\mathrm{TiB}_{\mathrm{x}}$. The oxide scale thickness of $\mathrm{Ti}_{0.9} \mathrm{Al}_{0.1} \mathrm{~B}_{1.3}$ and $\mathrm{Ti}_{0.9} \mathrm{Al}_{0.1} \mathrm{~B}_{1.9}$ after air annealing at $600{ }^{\circ} \mathrm{C}$ for $10 \mathrm{~h}$ was measured to be $205 \mathrm{~nm}$ and 320 $\mathrm{nm}$, respectively. Moreover, the trends indicate a reduced oxidation rate as the oxide scale grows thicker.

A systematical study of DCMS deposited $\mathrm{CrB}_{\mathrm{x}}$ coatings, $1.90 \leq x \leq 2.08$, was also performed, motivated by $\mathrm{CrB}_{\mathrm{x}}$ being a material of interest for providing potential corrosion resistance. All films, irrespectable of the deposition conditions, exhibited (0001) texture, with epitaxial growth observed when increasing temperature from 500 ${ }^{\circ} \mathrm{C}$ to $900{ }^{\circ} \mathrm{C}$. Higher density $\left(5.2 \mathrm{~g} / \mathrm{cm}^{3}\right)$ and smoother surfaces was seen in films grown at lower pressure, $5 \mathrm{mTorr}(0.67 \mathrm{~Pa})$, compared to higher pressure, $20 \mathrm{mTorr}(2.67 \mathrm{~Pa})$, and was explained by less gas scattering leading to more energetic particles impinging on the surface. $\mathrm{CrB}_{\mathrm{x}}$ film composition show no apparent dependence on substrate temperature, and has a slight dependence on deposition pressure for the samples deposited at $900{ }^{\circ} \mathrm{C}$, with reduced $\mathrm{B}$ content for increasing pressure. Overstoichiometric $\mathrm{CrB}_{2.08}$ films showed the presence of large B-rich inclusions, and B deficiency in $\mathrm{CrB}_{1.90}$ 
films presented as planar defects with Cr-rich stacking faults, similar to understoichiometric $\mathrm{TiB}_{\mathrm{x}}$.

The thorough investigations of all the systems in this thesis are aimed towards improving the understanding of the correlation between the thin film synthesis process and the resulting composition and microstructure, which in turn dictates the properties of thin films. A particular emphasis is put on control of composition.

Keywords: [DCMS, HiPIMS, Titanium Diboride, Titanium Aluminum Diboride, Chromium Diboride, Microstructure, Hardness, Oxidation Resistance] 



\section{SVENSK SAMMANFATTNING}

I den här avhandlingen fokuserar jag på beläggningar av tunna filmer, dvs. tunna lager av material som läggs på en yta för att ge ytan vissa specifika egenskaper. Jag genomför metodiska analyser av de filmer jag får från två olika beläggningsmetoder; "high-power impulse magnetron sputtering" (HiPIMS) och den mer konventionella metoden "directcurrent magnetron sputtering” (DCMS). Dessa metoder skiljer sig främst åt i antal parametrar man kan variera för att kontrollera processen som styr vilket material som bildas, där HiPIMS är den metod med flest parametrar. Anledningen till att HiPIMS inte har sett ett större användningsområde till dags dato är att det är en relativt ny process jämfört med DCMS, och på grund av den komplexitet som tillkommer när man utökar mängden tillväxtparametrar. För båda processerna är en grundläggande förståelse av både processen och materialet önskvärt för att få ett optimerat material, med specifika önskade egenskaper.

Material i fokus i denna avhandling är $\mathrm{TiB}_{\mathrm{x}}, \mathrm{Ti}_{1-\mathrm{x}} \mathrm{Al}_{\mathrm{x}} \mathrm{B}_{2-\mathrm{y}}$ och $\mathrm{CrB}_{\mathrm{x}}$, även kallade övergångsmetall-diborider, där Ti står för titan, Al för aluminium, Cr för krom, B för bor, och $x / y$ står för variabler i sammansättningen av materialet. Dessa diborider bär med sig unika egenskaper från respektive element och innehåller en blandning av kovalenta bindningar och jon-bindningar. Beroende på sammansättningen av atomer så kan vi se olika mekaniska, elektriska och termiska egenskaper samt olika grad av oxidering- och eroderings-resistans. $\mathrm{TiB}_{\mathrm{x}}$ är till exempel välkänt för sina tillämpningar inom skärande bearbetning, men har inte lika lovande egenskaper när det kommer till beständighet mot oxidering. Det här är delvis en konsekvens av att man idag kommersiellt använder sig främst av DCMS för tillväxt av dessa beläggningar, då denna metod typiskt genererar överstökiometriska tunna filmer av $\operatorname{TiB}_{\mathrm{x}}(x>2)$, vilket i sin tur påverkar beständigheten mot oxidering negativt.

Med hjälp av HiPIMS kan man kontrollera stökiometrin av filmen i större grad, och kan således generera understökiometrisk $\operatorname{TiB}_{\mathrm{x}}(x<2)$ som jag visar på har bättre 
mekaniska egenskaper, bland annat högre hårdhet, bättre brottseghet och förbättrad beständighet mot oxidering, kontra den överstökiometriska motsvarigheten. Hur mikrostrukturen i överstökiometriska $\mathrm{TiB}_{\mathrm{x}}$ filmer ser ut är välkänt, där överflödigt $\mathrm{B}$ ansamlas i korngränserna och bilder en s.k. "B-rik vävnadsfas”. Jag har påvisat hur motsvarande mikrostruktur ser ut för understökiometrisk $\mathrm{TiB}_{\mathrm{x}}$ filmer, något som fram tills nu varit okänt. I dessa faser saknas vävnadsfas i korngränserna, och istället hittas överskottet av Ti som plandefekter i de kolumnära $\mathrm{TiB}_{2}$-strukturerna i filmen. Jag visar på att avsaknaden av vävnadsfas i korngränserna tydligt förbättrar beständigheten mot oxidering, vilket troligtvis beror på att just korngränserna, och deras innehåll, agerar som en katalys for oxidering.

På samma sätt undersöker jag hur materialsystemet $\mathrm{Ti}_{1-\mathrm{x}} \mathrm{Al}_{\mathrm{x}} \mathrm{B}_{\mathrm{y}-2}$ beter sig med varierande Ti:Al förhållande och även $\mathrm{B}: \mathrm{M}$ förhållande (bor till metall), i filmer skapade med både DCMS och HiPIMS. Målet med inkluderingen av Al är just att förbättra beständighet mot oxidering, och samtidigt bevara de åtråvärda mekaniska egenskaperna som filmer $\mathrm{av} \mathrm{TiB}_{\mathrm{x}}$ har. Korngränserna i det här materialet består av en vävnadsfasblandning, rik på antingen $\mathrm{Al}$ eller $\mathrm{B}$, beroende på förhållandet mellan $x$ och $y \mathrm{i} \mathrm{Ti}_{1-}$ ${ }_{x} \mathrm{Al}_{\mathrm{x}} \mathrm{B}_{\mathrm{y}-2}$. Jag visar på att en reducering av denna vävnadsfas även här förbättrar beständigheten mot oxidering. Det påvisas genom att reducera $\mathrm{Al}$ - och $\mathrm{B}$-innehållet $\mathrm{i}$ filmerna, vilket minskar vävnadsfasen i korngränserna, och således förbättras beständigheten mot oxidering.

En systematisk undersökning av tunna filmer av $\mathrm{CrB}_{\mathrm{x}}$, belagda med DCMS, har genomförts, då detta är ett materialsystem med potential för beständighet mot korrosion. Både lätt över- och understökiometriska filmer växtes, och fick sin mikrostruktur och lokala sammansättning undersökt. Alla filmer påvisade en (001) textur, med epitaxiell tillväxt när temperaturen ökade från $500 \mathrm{C}^{\circ}$ till $900 \mathrm{C}^{\circ}$. Högre densitet $\left(\sim 5.2 \mathrm{~g} / \mathrm{cm}^{3}\right)$ och jämnare ytor sågs för filmer belagda vid lägre tryck, 5 mTorr (0.67 Pa), jämfört med högre tryck, 20 mTorr (2.67 Pa). Kompositionen för $\mathrm{CrB}_{\mathrm{x}}$ filmerna påvisade inte ett temperaturberoende, men visade ett marginellt beroende på beläggningstryck för prover växta vid $900 \mathrm{C}^{\circ}$. Även observerat för understökiometriska $\mathrm{CrB}_{1.90}$ filmer är att 
underskottet av B presenteras som plandefekter med Cr-rika plan i de kolumnära $\mathrm{CrB}_{2}$ strukturerna i filmen, precis som i understökiometrisk $\mathrm{TiB}_{\mathrm{x}}$. I överstökiometriska $\mathrm{CrB}_{2.08}$ filmer så visades stora inneslutningar av ansamlat B. 



\section{POPULÄRVETENSKAPLIG SAMMANFATTNING}

Mänskligheten strävar alltid åt att förbättra och förenkla tillvaron i form av produktutveckling, eller kanske till och med genom att uppfinna och tillverka helt nya produkter vi kanske inte ens visste att vi behövde. Idag sker en blandning av dessa två, där nya produkter i form av telefoner, datorer och diverse elektronik utvecklas genom att pusha befintlig teknologi till nya nivåer. Samtidigt så sker det emellanåt hela generationsskiften av produkter, där helt nyuppfunnen teknologi används. Exempel på detta kan ses i utvecklingen av kvantdatorer, där man försöker tillämpa kvantmekaniska egenskaper hos elementarpartiklar för att spara och transportera information. Nya stora revolutionerande steg kan även göras inom mjukvara, exempelvis utvecklingen av rörelsedetektion för tillämpningar i virtuella miljöer.

För att fortsätta att expandera den mänskliga kunskapen kring vår omvärld och utveckla nya produkter så bör man börja med en förståelse för de minsta fysikaliska byggstenar som vi idag kan hantera inom materialvetenskap; atomerna. För att förstå hur ett material beter sig när det exempelvis används i batterier, kretskort eller hårdhetsbeläggningar, så krävs det en grundläggande förståelse kring hur varje individuell atom samverkar med andra atomer. Tittar man till exempel på metallen titan så förekommer den ofta i människokroppen i form av artificiella implantat, då metallen är slittålig, kan hantera kroppsliga syror utan att erodera, och den skapar inte allergier. Ett annat exempel är bor, ett betydligt mindre förekommande halv-metalliskt element med begränsade tillämpningsområden i sin rena form. Båda elementen har sina egna unika egenskaper, men vad händer om vi kombinerar dem?

I den här avhandlingen gör jag just det, jag blandar flera olika element med unika egenskaper och får således ett nytt material med helt nya karaktärsdrag. Precis på samma sätt som man får grön färg genom att blanda blå och gul, så försöker jag blanda olika element för att förbättra egenskaper eller hitta någonting helt nytt. Materialen skapas med en metod som kallas sputtering, där jag tar en palett som kan bestå av ett eller flera 
olika element, exempelvis titan och bor, och stoppar in den i en kammare tillsammans med ett blankt prov (som metaforiskt skulle kunna vara ett pappersark som du ska måla den nya gröna färgen på). Sedan bombarderas paletten med partiklar, som i sin tur orsakar att titan- och boratomer, slungas iväg från paletten så som en asteroid slungar upp sten och jord när den träffar jordytan, fast då på en betydligt mindre skala. Dessa uppslungade titan- och boratomer färdas sen mot mitt blanka prov, och fäster sig på dess yta.

Den här processen upprepas tills man fått en beläggning på mitt tidigare tomma prov. Beroende på hur atomerna placerar sig, eller hur mycket av varje atom jag har, så kan min beläggning få helt olika egenskaper. Målet är att kombinera de bästa egenskaperna från respektive element, eller att få helt nya egenskaper som de individuella elementen inte hade från början. På detta vis har jag jobbat med titan, aluminium och bor för att bilda titandiborid och en så kallad legering, titanaluminiumdiborid, i syfte att förbättra och utveckla nästa generations hårda material för till exempel skärande och bearbetande verktyg. Vi har även undersökt krom kombinerat med bor, för att undersöka om man i framtiden kan skapa mer tåliga material som kan passa i kemiskt omgivningar där aggressiv korrosion förekommer. 


\section{PREFACE}

This thesis is a perceptible summary of my Ph.D. studies in the Thin Films Physics Division, the Materials Design unit, at Linköping University. I present material synthesis and characterization performed in collaboration with national and international research groups. The long-term goal is to explore the potential of metal diborides for the next generation of hard coating materials.

The work was funded by the Knut and Alice Wallenberg (KAW) foundation, with additional support from the Swedish Government Strategic Research Area in Materials Science, Advanced Functional Materials, at Linköping University. 



\section{ACKNOWLEDGEMENTS}

I would like to express my deepest gratitude towards Johanna Rosen for inspiring me alraedy in your project courses during my bachelor's education. You have been a source of inspiration for many years with your gentle, but stern, supervision, and you have always been very empathetic towards my goals and aspirations outside academia. I do not believe I would have achieved what I have today without your guidance.

I also want to thank Joseph Halim for being a great mentor, and an even greater friend. You have always been a person I can turn to if I feel stressed about work, or are in need of advice. I'm looking forward to a life-long friendship with you.

To my newest colleague, Fedor Klimashin, I want to thank for all the quality workouts we have done together. Even though you are a bit to slow on the bike and intrusive on the run, I still love your company. I foresee us sharing many more great experiences in the future!

Mohsin Raza, for sharing and cooking food with me the last year(s) during my $\mathrm{PhD}$ studies. It is with great pleasure I tell you that I will have you make me food indefinitely, even if you move to Göteborg.

Andrejs Petruhins, for always helping me with Laura and Hydra. I believe Johanna (and all her employees) are very fortunate to have you at their disposal when things do not work, and most importantly, when switching magnetrons!

Maija Vilkina, for being a fantastic mother to our daughter Tilda and a great supporter for my seemingly impossible endeavors in life.

My mother, Vanja, who has made my life easier time and again, every which way and any which way possible. 
Finally, my wife Caroline. Being with you is like being able to witness a sunset over the horizon to the sound of ocean waves breaking on shore, every day. You are the best cat in my life, and you make me want to be the best person I could possibly be. Thank you for being the sunlight in my life, and bringing Loke into our lives! 


\section{INCLUDED PAPERS AND AUTHOR'S CONTRIBUTION}

Paper I Microstructure and Materials Properties of Understoichiometric TiB $_{x}$ Thin Films Grown by HiPIMS.

Jimmy Thörnberg, Justinas Palisaitis, Niklas Hellgren, Fedor F. Klimashin, Naureen Ghafoor, Igor Zhirkov, Clio Azina, Jean-Luc Battaglia, Andrzej Kusiak, Maurico A. Sortica, J.E. Greene, Lars Hultman, Ivan Petrov, Per O.A. Persson, Johanna Rosen.

Surface \& Coatings Technology, 126537 (2020)

Main-author - Responsible for the film growth using DCMS and HiPIMS. Performed XRD, SEM and EDX analyses, and interpreted results. Responsible for writing and iterating the original draft with coauthors.

Paper II Improved Oxidation Properties from a Reduced B Content in Sputter-Deposited TiB $_{\mathbf{x}}$ Thin Films.

Jimmy Thörnberg, Babak Bakhit, Justinas Palisaitis, Niklas Hellgren, Lars Hultman, Grzegorz Greczynski, Per O.A. Persson, Ivan Petrov, Johanna Rosen.

In Manuscript

Main-author - Responsible for the film growth using DCMS and HiPIMS and air annealing of the films. Performed XRD, SEM and EDX analyses, and interpreted results. Responsible for writing and iterating the original draft with co-authors.

Paper III Oxidation resistance and mechanical properties of sputterdeposited Tio.9Al $\mathbf{A l}_{0.1} \mathbf{B}_{2-y}(y: 0.1-0.7)$ metal boride thin films.

Jimmy Thörnberg, Stanislav Mráz, Justinas Palisaitis, Fedor F. Klimashin, Pavel Ondracka, Lars Hultman, Ivan Petrov, Per O.Å. Persson, Peter Polcik, Szilard Kolozsvaric, Jochen M. Schneider, Johanna Rosen.

In Manuscript

Main-author - Responsible for the film growth using DCMS and HiPIMS and air annealing of the films. Performed XRD, SEM and EDX 
analyses, and interpreted results. Responsible for writing and iterating the original draft with co-authors.

Paper IV Synthesis and Characterization of $\mathrm{CrB}_{\mathbf{x}}$ Thin Films grown by DC Magnetron Sputtering.

Megan Dorri, Jimmy Thörnberg, Justinas Palisaitis, Andrejs Petruhins, Fedor F. Klimashin, Niklas Hellgren, Lars Hultman, Ivan Petrov, Per O.Å. Persson, Johanna Rosen.

In Manuscript

Main-author (second author, equal contribution with the first author) Assisted in film growth using HiPIMS and writing of the original draft together with the first author. Assisted in interpretation of results. Assisted in writing and iterating the original draft with co-authors.

Paper V High-power Impulse Magnetron Sputter Deposition of $\mathbf{T i B}_{\mathbf{x}}$ Thin Films: Effects of Pressure and Growth Temperature.

Niklas Hellgren, Jimmy Thörnberg, Igor Zhirkov, Maurico A. Sortica, Ivan Petrov, Joseph E. Greene, Lars Hultman, Johanna Rosen.

Vacuum, 169, 108884 (2019)

Co-author - Assisted in film growth using DCMS and HiPIMS. Performed XRD, SEM and EDX analyses, and assisted in the review and editing process of the original draft. 


\section{PAPERS NOT INCLUDED IN THE THESIS}

Paper VI Where is the Unmatched Transition Metal in Substoichiometric Diboride Line Compounds?

Justinas Palisaitis, Martin Dahlqvist, Allen J. Hall, Jimmy Thörnberg, Ingemar Persson, Nils Nedfors, Lars Hultman, J.E. Greene, Ivan Petrov, Johanna Rosen, Per O.A. Persson.

Acta Materialia, 116510 (2020)

Co-Author - Assisted in the review and editing process of original draft.

Paper VII Improving the High-Temperature Oxidation Resistance of $\mathrm{TiB}_{2}$ Thin Films by Alloying with Al.

Babak Bakhit, Justinas Palisaitis, Jimmy Thörnberg, Johanna Rosen, Per O.Å. Persson, Lars Hultman, Ivan Petrov, J.E. Greene, Grzegorz Greczynski.

Acta Materialia, 196, 667-689 (2020)

Co-Author - Assisted in the review and editing process of original draft.

Paper VIII Synthesis of $\left(\mathrm{V}_{2 / 3} \mathrm{Sc}_{1 / 3}\right)_{2} \mathrm{AIC} i$-MAX Phase and $\mathrm{V}_{2-x} \mathrm{C}$ MXene Scrolls.

Jimmy Thörnberg, Joseph Halim, Jun Lu, Rahele Meshkian, Justinas Palisaitis, Lars Hultman, Per O.A. Persson and Johanna Rosen.

Nanoscale, 11, 14720 (2019)

Main-Author - Responsible for the planning of bulk synthesis using sintering furnace and responsible for the MXene fabrication using various etching methods ( $\mathrm{HF}, \mathrm{HCl}+\mathrm{LiF}$ and $\mathrm{NaF}+\mathrm{HCl})$ and delamination processes. Did analyses with XRD, SEM and EDX. Responsible for writing and iterating the original draft with co-authors

Paper IX W-Based Atomic Laminates and Their 2D Derivative W1.33C MXene with Vacancy Ordering.

Rahele Meshkian, Martin Dahlqvist, Jun Lu, Björn Wickman, Joseph Halim, Jimmy Thörnberg, Quanzheng Tao, Shixuan Li, Saad Intikhab, Joshua Snyder, Michel W. Barsoum, Melike Yildizhan, Justinas Palisaitis, Lars Hultman, Per O.Å. Persson, Johanna Rosen. 
Advanced Materials, 30 (21), 1706409 (2018)

Co-Author - Assisting in the MXene fabrication using various etching methods. Performed XRD, SEM and EDX analyses. Assisted in the review and editing process of the original draft.

Paper X Theoretical Analysis, Synthesis, and Characterization of 2D $\mathrm{W}_{1.33} \mathrm{C}$ (MXene) with Ordered Vacancies.

Rahele Meshkian, Hans Lind, Joseph Halim, Ahmed El Ghazaly, Jimmy Thörnberg, Quanzheng Tao, Martin Dahlqvist, Justinas Palisaitis, Per O.Å. Persson, Johanna Rosen.

ACS Applied Nano Materials, 2 (10), 6209-6219 (2019)

Co-Author - Assisting in the MXene fabrication using various etching methods. Performed XRD, SEM and EDX analyses. Assisted in the review and editing process of the original draft.

Paper XI Out-of-plane ordered laminate borides and their two-dimensional Ti-based derivative from chemical exfoliation.

Martin Dahlqvist, Jie Zhou, Ingemar Persson, Bilal Ahmed, Jun Lu, Joseph Halim, Quanzheng Tao, Justinas Palisaitis, Jimmy Thörnberg, Pernilla Helmer, Lars Hultman, Per O.Å. Persson, Johanna Rosen.

Submitted - Advanced Materials

Co-Author - Assisting in bulk synthesis using sintering furnace. 


\section{TABLE OF CONTENTS}

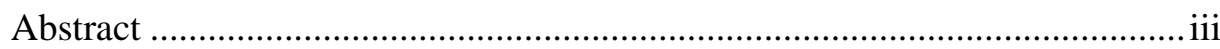

Svensk Sammanfattning .......................................................................... vii

Populärvetenskaplig Sammanfattning ......................................................... xi

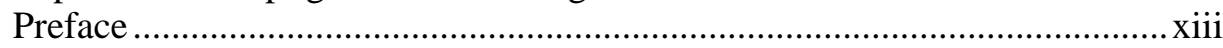

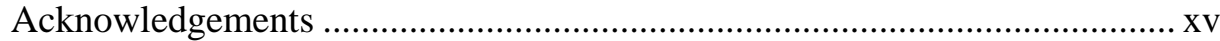

Included Papers and Author's Contribution .................................................xvii

Papers Not Included In The Thesis............................................................... xix

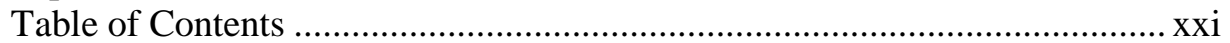

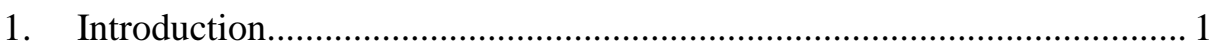

1.1. Thin Film Technology ................................................... 1

1.2. Background - Metal Borides........................................... 1

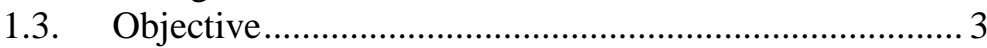

1.4. Outline of Thesis.......................................................... 4

2. Transition Metal Diborides ..................................................................... 5

2.1. Oxidation Kinetics of Borides and Beyond ................... 7

2.2. Titanium Diboride ....................................................... 9

2.3. Titanium Aluminum Diborides..................................... 12

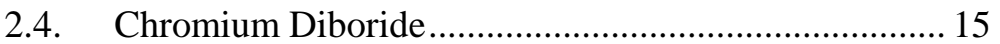

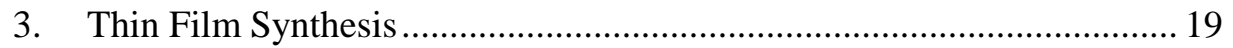

3.1. Thin Film Deposition Techniques ................................ 19

3.2. Sputtering................................................................ 19

3.3. Magnetron Sputtering ................................................... 20

3.4. High Power Impulse Magnetron Sputtering ................. 21

4. Thin Film Characterization Techniques ................................................. 25

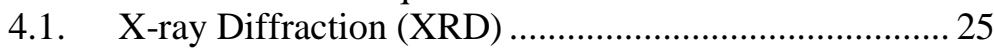

4.2. Scanning Electron Microscope (SEM) …….................22

4.3. Transmission Electron Microscopy (TEM) …...............28

4.4. Energy Dispersive X-Ray Spectroscopy (EDX)............ 30

4.5. X-ray Photoelectron Spectroscopy (XPS) ..................... 31

4.6. Elastic Recoil Detection Analysis (ERDA) ....................32

4.7. Rutherford Backscattering Spectrometry (RBS) .......... 33

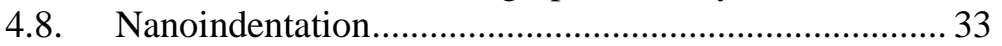

4.9. Photo Thermal Radiometry (PTR) ................................. 34

5. Summary and Contribution to the Field …………................................... 37

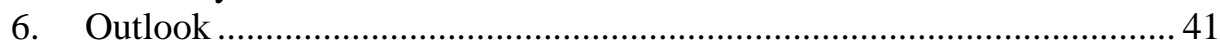

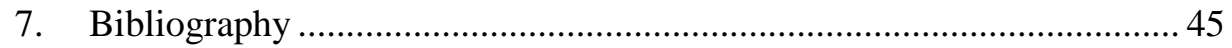





\section{INTRODUCTION}

\subsection{Thin Film Technology}

Thin films are layers of material ranging from a thickness of a few atomic layers to several micrometers. In our modern age, thin film based technologies and applications surround us. The applications include everything from our everyday life, be it a frying pan with the synthetic fluoropolymer Teflon technology, or glass windows with heatfiltering silver coatings for heat preservation. Smartphones with electrical components and touchscreens coated with wear- and corrosive-resistant materials for enhanced durability and conductivity are other examples. Similarly, in industry, thin-film coatings are used to increase the lifetime and range of operation for cutting tools. The applications are seemingly endless with an ever-increasing demand of tailored materials that can be used for specific purposes.

\subsection{Background - Metal Borides}

This work is related to thin film synthesis of metal diborides and alloys thereof, a subclass of metal borides. Borides are a family of compounds seen both in bulk form and as thin films, ${ }^{1}$ where boron (B) atoms are typically bonded to a less electronegative element, generally a metal (M). ${ }^{2,3}$ A generally accepted definition of metal borides divides them into two sub-groups, B-rich and M-rich. The foremost implies a ratio of significantly more $B$ than $M$, with a B:M ratio of 4:1 and higher, while the latter goes below the 4:1 B:M ratio. B-rich metal borides vary largely in characteristics. In the field of thermoelectricity we can find the divalent calcium and strontium hexaboride, $\mathrm{CaB}_{6}$ and $\mathrm{SrB}_{6}$, along with the boron rich $\mathrm{YB}_{48}$, all showing great thermoelectric properties at high temperatures. ${ }^{4-7}$ In addition, there are B-rich metal borides exhibiting magnetic, semiconducting or superconducting properties. ${ }^{8}$ Trends show that borides with transition metals (TM) favor the formation of M-rich borides, which are generally inert with a high melting temperature. We can also find examples of the hard and strength reinforcing titanium diboride $\left(\mathrm{TiB}_{2}\right)$, the superconducting magnesium diboride $\left(\mathrm{MgB}_{2}\right)$, 
and the ultra-incompressible osmium diboride $\left(\mathrm{OsB}_{2}\right)$, which are all so-called linecompounds. ${ }^{9-11}$

In thin film form, the transition-metal diboride $\mathrm{TiB}_{2}$ is a good hard-coating material with high chemical stability, ${ }^{12}$ a few of its many desirable attributes, that can significantly reduce the degradation of the tools and machine parts surfaces. ${ }^{13,14} \mathrm{In}$, particular, the material can be used for machining Al. Furthermore, very interesting and desirable properties are found in $\mathrm{TiB}_{\mathrm{x}}$ thin films with excess $\mathrm{B}$. The B:TM ratio typically vary locally in the thin film, due to the segregation of a B-rich tissue phase in the grain boundaries of $\mathrm{TiB}_{\mathrm{x}}$. Reports show the expected 2:1 B:TM ratio in $\mathrm{TiB}_{\mathrm{x}}$ nanocolumnar crystals, separated by this B-rich tissue phase. ${ }^{15,16}$ The tissue phase gives a high hardness, however, the mechanical properties are held back somewhat by the limited fracture toughness and oxidation resistance. ${ }^{17}$ Until recently, corresponding knowledge of understoichiometric, or M-rich $\mathrm{TiB}_{\mathrm{x}}$, was missing, which is part of the present thesis. Another line compound is $\mathrm{CrB}_{2}$, which is less explored in thin film form, but are known to exhibit superior corrosive resistance, while maintaining good mechanical properties. This makes $\mathrm{CrB}_{\mathrm{x}}$ films excellent for high temperature structural applications and hard coatings for tools and dies. ${ }^{18,19}$

$\mathrm{Ti}_{\mathrm{y}} \mathrm{Al}_{1-\mathrm{y}} \mathrm{B}_{\mathrm{x}}$ in the form of a metal diboride alloy is not extensively explored, but it displays a high hardness. ${ }^{20,21}$ Furthermore, a recent study on supply of excess $\mathrm{Al}$ during deposition of $\mathrm{TiB}_{2}$, forming a metal-rich compound, indicates enhanced oxidation resistance properties. ${ }^{17}$ This motivates the exploration of alloying between $\mathrm{Al}$ in $\mathrm{TiB}_{\mathrm{x}}$, to study oxidation resistance as well as mechanical properties, for varying $\mathrm{B}$ content as well as different Ti:Al metal ratios. Control of thin film composition may facilitate identification of the synthesis parameter space that will allow optimization of multiple properties. Therefore, fundamental understanding of thin films synthesis process, and control of the resulting film formation, is required. 


\subsection{Objective}

The purpose of this thesis is to explore growth and characterization of metal diborides in thin film form, and to achieve fundamental understanding of plasma generation, transport, and condensation off thin film growth by magnetron sputtering. Of particular interest is to increase the understanding of how synthesis parameters such as substrate temperature, sputtering gas and pressure, target power, and material flux, can influence film composition and microstructure, and consequently the materials properties. This is systematically explored for $\mathrm{TiB}_{\mathrm{x}}$ and $\mathrm{CrB}_{\mathrm{x}}$. In particular, the uncharted properties and microstructure of $\mathrm{TiB}_{\mathrm{x}}$ with $x<2$ is investigated and compared with corresponding films with $x>2$.

In literature, a Ti-Al-B material systems show a reduced oxidation rate with the addition of $\mathrm{Al}$, due to the formation of a protective $\mathrm{Al}_{2} \mathrm{O}_{3}$ oxide scale on the film surface. However, this at the expense of the excellent mechanical properties found in the pure $\mathrm{TiB}_{\mathrm{x}}$ system. This motivates an investigation of $\mathrm{Al}$ alloying in $\mathrm{TiB}_{\mathrm{x}}$, to explore if the mechanical properties, as observed in $\mathrm{TiB}_{\mathrm{x}}$, can be retained also after inclusion of with $\mathrm{Al}$, while also achieving the desirable oxidation kinetics seen in other Al-based compounds. Property tuning for $\mathrm{TiB}_{\mathrm{x}}$ and $\mathrm{Ti}_{1-\mathrm{x}} \mathrm{Al}_{x} \mathrm{~B}_{2-\mathrm{y}}$ by varying $x$ and $y$ is therefore studied.

The investigations were performed both in lab scale and industrial scale deposition systems, using the conventional physical vapor deposition (PVD) technique direct-current magnetron sputtering (DCMS) and the more recent PVD technique highpower impulse magnetron sputtering (HiPIMS). The combination of these techniques allows the comparison of film crystal structure, composition and properties as a function of a wide range of deposition parameters. DCMS is an established PVD method, while HiPIMS offers a larger space of growth parameters. This, however, also significantly increase the complexity. DCMS and HiPIMS are complementary since the former technique show indications of producing $\mathrm{TiB}_{\mathrm{x}}$ films with a higher $\mathrm{B}$ content than the latter technique. Hence, thin films with a wide range of B:TM ratios are attainable. 
Investigation of the microstructure, mechanical, electrical, and thermal properties as well as oxidation and erosion resistances is studied for films with varying compositions.

\subsection{Outline of Thesis}

A brief introduction is given of metal diborides, followed by a more focused introduction of the relevant $\mathrm{TiB}_{\mathrm{x}}, \mathrm{CrB}_{\mathrm{x}}$ and $\mathrm{Ti}_{1-\mathrm{x}} \mathrm{Al}_{\mathrm{x}} \mathrm{B}_{2-\mathrm{y}}$ material systems. This is followed by a short introduction to the basics of PVD, including sputtering, magnetron sputtering and finally HiPIMS, covering recent development using the latter technique for metal diboride depositions. A brief summary of the field for each respective material system, with the addition of my results, is then presented, and a brief description of the analytical tools used to characterize the films. At the end of thesis, a summary of my contributions to the field and an outlook is given. 


\section{TRANSITION METAL DibORIDES}

TM diborides are defined as a combination of an element with partially occupied dorbitals from group 4 to 11 in the periodic table, including the f-block lanthanide and actinides, and boron, with an unpaired electron with three-bonding electronic functions. Here a bonding molecular orbital (MO) is doubly occupied while the corresponding antibonding $\mathrm{MO}$ is singly occupied. ${ }^{22}$ Together they typically form an $\mathrm{AlB}_{2}$ type structure (hexagonal P6/mmm, SG-191), see example of $\mathrm{TiB}_{2}$ in Figure 1, where the Blayer is essentially a hexagonal graphite-like layer with all its sites occupied. ${ }^{23}$

Between these honeycomb-like layers we find a transition metal, in a top view located in the center of the hexagonal prisms formed by the boron sheet. The $\mathrm{AlB}_{2}$ structure type is the most common arrangement found for the TM diborides. ${ }^{23}$ Within this structure we find covalent B-B bonding and interlayer TM-B bonds of more ionic character, giving the material its wide span of both ceramic and metallic characteristics. Hardness, stiffness and melting-temperatures of TM diborides can be credited to TM-B bond mixture of covalent and ionic, ${ }^{23}$ while properties such as electrical and thermal conductivities depend on the intermetallic bonds. ${ }^{24}$ These materials systems are of scientific and industrial interest due to their range of properties, see Table $\mathbf{1}$ for an assortment of some well-known TM diborides and their respective properties.
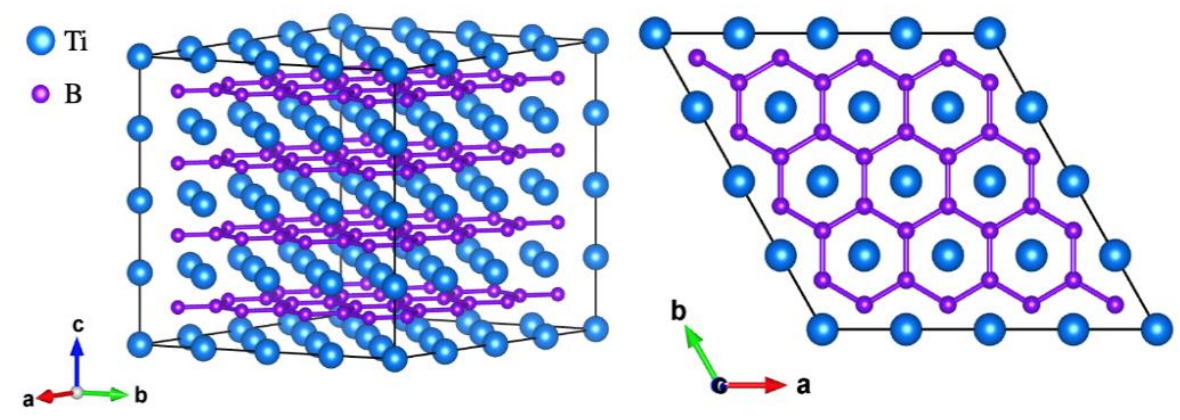

Figure 1 - Side- and top-view of a 192-atom, $4 \times 4 \times 4$ unit cell of $\mathrm{TiB}_{2}$ in an $\mathrm{AlB}_{2}$ structure (hexagonal P6/mmm, SG-191). 
Table 1 - Summary of selected mechanical, thermal and electrical properties of well-known transition-metal diborides. ${ }^{11,26-31}$

\begin{tabular}{|c|c|c|c|c|c|}
\hline Material & $\mathbf{T i B}_{2}$ & $\mathrm{ZrB}_{2}$ & $\mathrm{HfB}_{2}$ & $\mathbf{T a B}_{2}$ & $\mathbf{N b B}_{2}$ \\
\hline $\begin{array}{c}\text { Melting Point } \\
\left({ }^{\circ} \mathrm{C}\right)\end{array}$ & 3225 & 3200 & 3380 & 3040 & 3036 \\
\hline $\begin{array}{l}\text { Density } \\
\left(\mathrm{gcm}^{-3}\right)\end{array}$ & 4.5 & 6.1 & 11.2 & 12.5 & 6.9 \\
\hline $\begin{array}{l}\text { Thermal Conductivity } \\
\qquad\left(\mathbf{W m}^{-1} \mathbf{K}^{-1}\right)\end{array}$ & $60-120$ & 60 & 104 & - & - \\
\hline $\begin{array}{c}\text { Electrical Resistivity } \\
(\mu \Omega \mathrm{cm})\end{array}$ & $9-15$ & $10-32$ & 11 & 33 & - \\
\hline $\begin{array}{c}\text { Elastic Modulus } \\
\text { (GPa) }\end{array}$ & $500-560$ & $340-550$ & 480 & $248-551$ & 637 \\
\hline $\begin{array}{c}\text { Hardness } \\
\text { (GPa) }\end{array}$ & $25-45$ & $20-25$ & $21-28$ & $20-25$ & 21 \\
\hline $\begin{array}{c}\text { Fracture Toughness } \\
\qquad\left(\mathrm{MPam}^{1 / 2}\right)\end{array}$ & $4-5$ & 4 & - & 4.5 & 4 \\
\hline
\end{tabular}

Among those are TM diborides with an "ultra-high melting point" exceeding $3000{ }^{\circ} \mathrm{C}$, a term that was introduced in the early 1990s to identify a class of materials containing candidates for rocket engines and thermal protection for spacecraft and hypersonic aerospace vehicles. ${ }^{25}$ Another interesting aspect of TM diborides is how slight deviations from the nominal stoichiometry significantly affects most of the material properties. As such, systematic studies and investigations are commonly formulated around compositional control and how said composition affects the TM diborides properties.

Further tuning of materials properties can be done through synthesis of multicomponent systems, allowing for enhanced functionality through additional control of composition and microstructure. ${ }^{32,}{ }^{33}$ In the field of TM diborides, a few ternary systems have been explored so far. Examples of such a structure and atomic 
configuration is seen in Figure 2, showing a disordered $\mathrm{Ti}_{0.5} \mathrm{Al}_{0.5} \mathrm{~B}_{2}$ supercell. ${ }^{34}$ Computational and experimental work has been done on the $\mathrm{W}_{1-\mathrm{x}} \mathrm{Ta}_{\mathrm{x}} \mathrm{B}_{2-\mathrm{x}}$ system, ${ }^{35,}, 36$ showing that by alloying $\mathrm{WB}_{2}$ with $\mathrm{Ta}$, the mechanical strength and ductility can be improved. Also observed is the ability to shift the temperature of decomposition and phase transformation from $800-1000{ }^{\circ} \mathrm{C}$ for the binary $\mathrm{WB}_{2-\mathrm{z}}$, to $1200-1400{ }^{\circ} \mathrm{C}$ for the multicomponent $\mathrm{W}_{1-\mathrm{x}} \mathrm{Ta}_{\mathrm{x}} \mathrm{B}_{2-\mathrm{z}}$.

Alloying a $\mathrm{ZrB}_{2}$ diboride with Ta has also been reported, ${ }^{37}$ showing improved mechanical properties when going from $\mathrm{ZrB}_{2.4}$ to $\mathrm{Zr}_{0.8} \mathrm{Ta}_{0.2} \mathrm{~B}_{1.8}$, with the hardness improving from $35.0 \pm 0.8 \mathrm{GPa}$ to $42.3 \pm 0.9 \mathrm{GPa}$ and the elastic modulus from $480 \pm 8 \mathrm{GPa}$ to $503 \pm 9 \mathrm{GPa}$. These values were further increased by annealing in $\mathrm{Ar}$ and it was explained by point-defect recovery in the films (defects localized to single lattice points, consisting of one or a few missing atoms). Alloying $\mathrm{TiB}_{2}$ with $\mathrm{Al}$ has also been done, ${ }^{20}$, ${ }^{21}$ and is discussed later in the thesis.

\subsection{Oxidation Kinetics of Borides and Beyond}

Important properties for hard coatings are not only their refractory characteristics, but also their kinetics of oxidation, a property that heavily influences the longevity for hard coatings. Formation of an oxide film on top of a hard coating is inevitable and the general physics behind it is well known. ${ }^{38,} 39$ Simplified, several processes can occur when an oxide scale starts forming on a metal surface. The oxide scale produced could
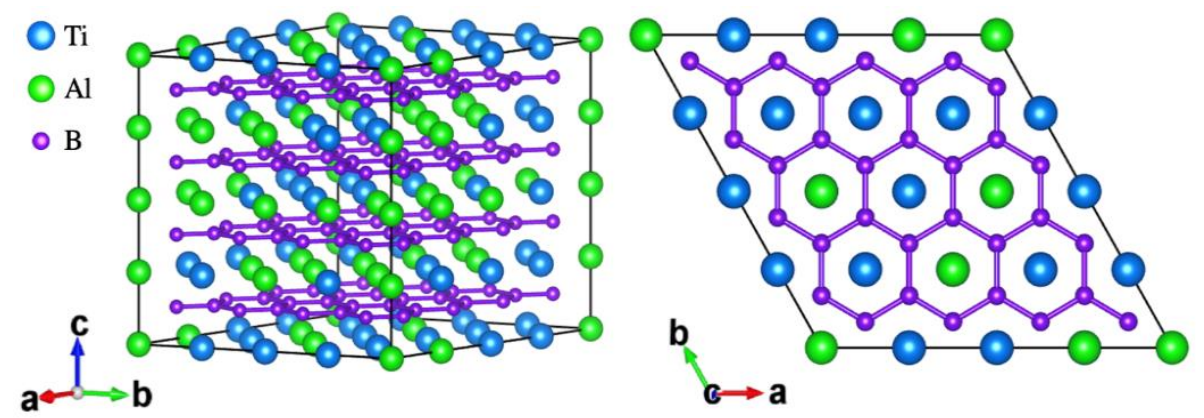

Figure 2 - Side- and top-view of a disordered 192-atom, 4x4x4 unit cell of $\mathrm{Ti}_{0.5} \mathrm{Al}_{0.5} \mathrm{~B}_{2}$ in an $\mathrm{AlB}_{2}$ structure (hexagonal P6/mmm, SG191). 
be very porous, allowing for $\mathrm{O}$ to pass through largely unhindered and continuously react at the oxide-metal interface. If the oxide scale is not porous enough, diffusion through the oxide is the rate-limiting step. The rate of oxidation also depends on the temperature, ${ }^{40}$ which affects diffusion, and also breakaway effects where the oxide film delaminates and/or spalls, exposing the metal surface for further oxidation. Three important mechanisms within oxidation behavior in metals are the linear, parabolic and hyperbolic oxidation rates. With a linear oxidation rate, a material oxidizes continuously and forms an oxide scale that grows at a constant rate. With a parabolic oxidation rate, the formation of an oxide scale tapers off as the oxide scale thickness grows, but never completely seizes. This is the rate in which most metals oxidize. The hyperbolic oxidation rate causes the oxide formation to completely taper off once reaching a critical oxide scale thickness. The rates of oxidation are illustrated in Figure 3. These mechanisms are determine by the nature in which a material oxidizes when exposed to O. Finding a hard coating with refractory characteristics and with hyperbolic oxidation kinetics is of great interest.

One of the most well studied TM diborides is $\mathrm{TiB}_{2}$, described in more detail below. A major drawback of $\mathrm{TiB}_{2}$ hard coatings is their poor oxidation resistance, with close to linear oxidation rates. Several investigations have been done on the oxidation

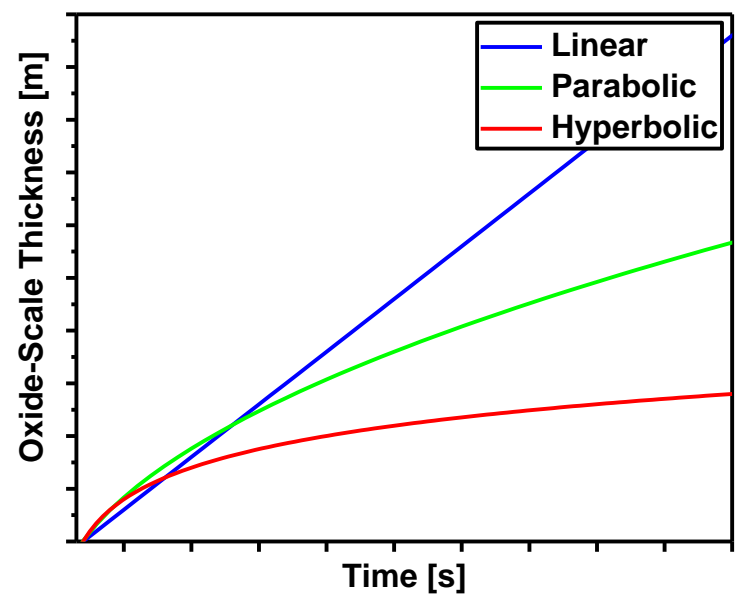

Figure 3 - Illustration of oxidation rates showing linear, parabolic, and logarithmic processes. 
behavior of $\mathrm{TiB}_{2}$, showing that the oxidation products generally consist of $\mathrm{B}_{2} \mathrm{O}_{3}$ and $\mathrm{TiO}_{2}$-phases, ${ }^{41-43}$ that form around $400-450{ }^{\circ} \mathrm{C}$. 44,45 The surface protection is largely dependent on $\mathrm{O}$ diffusion through $\mathrm{B}_{2} \mathrm{O}_{3}$ in capillaries of porous $\mathrm{TiO}_{2}$ skeletons. ${ }^{42}$ However, $\mathrm{B}_{2} \mathrm{O}_{3}$ is hydroscopic by nature and forms metaboric $\left(\mathrm{HBO}_{2}\right)$ and boric acid $\left(\mathrm{H}_{3} \mathrm{BO}_{3}\right)$ in the presence of water vapor, both acids gaseous at $+140{ }^{\circ} \mathrm{C} .{ }^{46-48}$ This results in a rapid evaporation of $\mathrm{B}_{2} \mathrm{O}_{3}$ in metal diborides in the presence of water vapor at increased temperatures, having a considerable effect on the oxidation properties of metal diborides. The process is more thoroughly explained in for $\mathrm{TiB}_{\mathrm{x}}$ in Paper II.

\subsection{Titanium Diboride}

Titanium diboride, $\mathrm{TiB}_{2}$, is a well-researched ceramic in the $\mathrm{TM}$ diboride family. It attracts attention due to desirable refractory characteristics commonly found in TM diborides, such as extreme hardness, good thermal stability, high thermal and electrical conductivity, and good mechanical erosion resistance. ${ }^{49-56}$ In $\mathrm{TiB}_{\mathrm{x}}$, these properties originate from the mixture of bonds, where B-B shows strong covalent bonding in the B plane, while the interaction between the layers is given by a mixture of covalent and ionic bonds between the B-TM atoms. ${ }^{57}$

Today, the majority of scientific studies are done on overstoichiometric $\mathrm{TiB}_{\mathrm{x}}$ coatings deposited by DCMS (further discussed in Chapter 3). In these films, excess B has migrated to the grain boundaries forming an amorphous B-rich tissue phase interlacing dense nanocolumnar $\mathrm{TiB}_{\mathrm{x}}$ structures, as seen in Figure 4 in plan-view STEM images acquired from overstoichiometric $\mathrm{TiB}_{\mathrm{x}}$ films, a)-b) $\mathrm{TiB}_{2.7}$ and $\mathbf{c}$ )-d) $\mathrm{TiB}_{2.1}$, with no discernable porosity or open boundaries. This microstructure, combined with the presence of a B tissue phase, significantly limits nucleation, slip dislocation and grain boundary sliding from occurring. ${ }^{15}, 16$ Even for large B/Ti ratios, the films retain the $\mathrm{AlB}_{2}$-hexagonal structure, though with expanding lattice constants. ${ }^{15}$ The numerous reports on overstoichiometric $\mathrm{TiB}_{\mathrm{x}}$ thin films are also reflected in the well-established material properties. Hardness for sputtered $\mathrm{TiB}_{\mathrm{x}}$ thin films, with $2.1 \leq x \leq 2.3$, displayed a linear increase from $38 \mathrm{GPa}$, at $x=2.1$, to $52 \mathrm{GPa}$, at $x=2.3{ }^{15}$ Theoretical investigations using first-principle calculations along with experimental studies suggest 
that excess $\mathrm{B}$ is incorporated in $\mathrm{TiB}_{\mathrm{x}}$ samples in a several ways. ${ }^{15}$ As bulk interstitials, which also increases the density, ${ }^{58}$ and in Ti vacancies. Still, considering that TiB2 is a line compound, this requires further detailed theoretical and experimental investigations.

The effect of even more overstoichiometric $\mathrm{TiB}_{\mathrm{x}}$ films on the properties has been studied for sputtered $\mathrm{TiB}_{\mathrm{x}}$ thin films, achieving compositions with $2.4 \leq x \leq 3.2 .{ }^{16}$ The microstructure could be described as $\sim 20 \mathrm{~nm}$ in diameter columns, encapsulated in excess B. The columns, in turn, consisted of several $\mathrm{TiB}_{2}$ subcolumns, $\sim 5 \mathrm{~nm}$ in diameter, separated by an ultrathin B-rich tissue phase. These nanocolumnar $\mathrm{TiB}_{\mathrm{x}}$ structures showed hardness values, irrespective of $x$, at $60 \sim \mathrm{GPa}$. While overstoichiometric $\mathrm{TiB}_{\mathrm{x}}$ films to some extent display excellent mechanical properties,
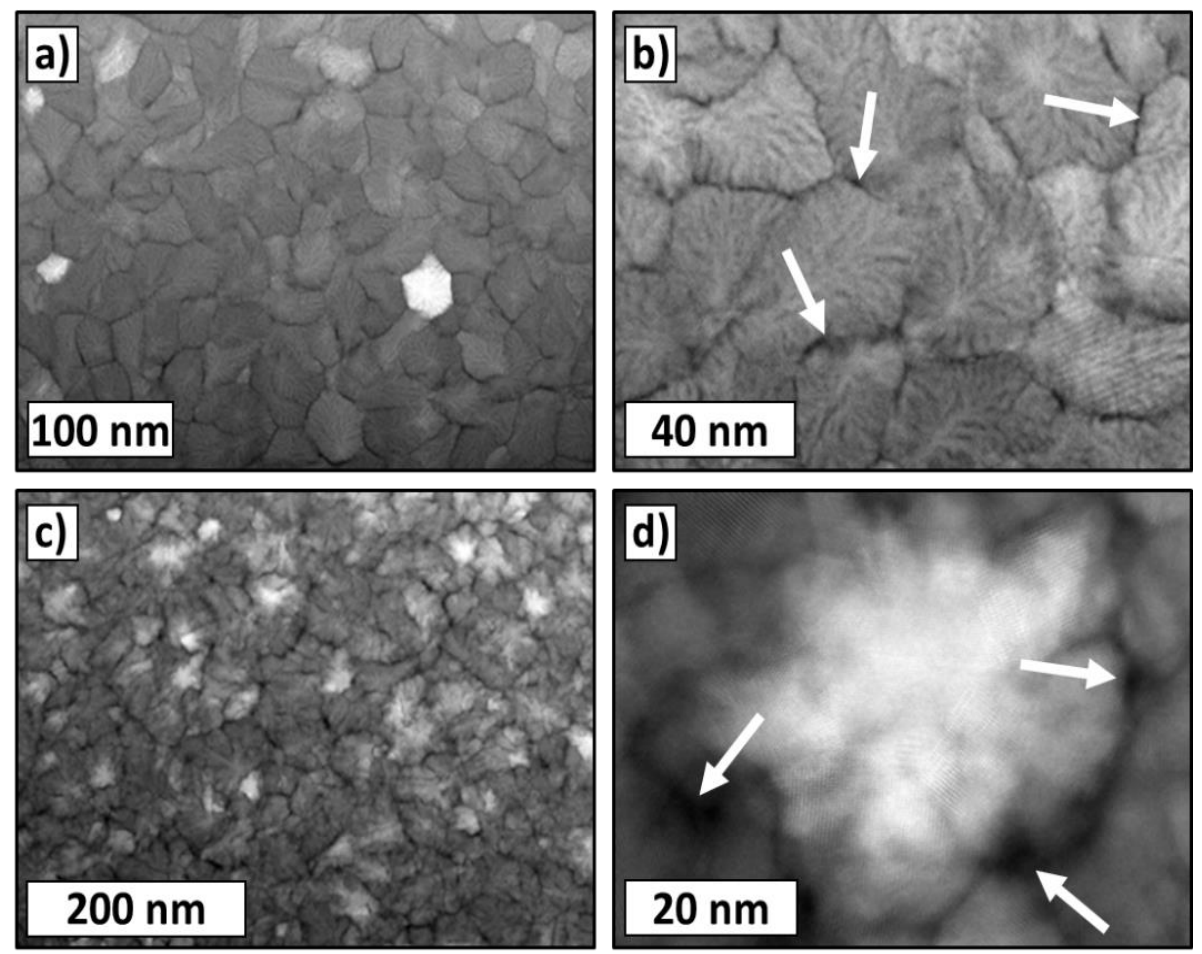

Figure 4 - Plan-view STEM images acquired from a)-b) $\mathrm{TiB}_{2.7}$ and c)d) $\mathrm{TiB}_{2.1}$, showing a dense columnar structure with B-tissue phase indicated by arrows, presented as darker regions between grains. 
the films are held back by limited fracture toughness and oxidation resistance, significantly inhibiting applications of $\mathrm{TiB}_{\mathrm{x}}$ films in aggressive environments. ${ }^{17}$

Investigations on understoichiometric $\mathrm{TiB}_{\mathrm{x}}$ coatings deposited with HiPIMS have only appeared once in literature to date, ${ }^{59}$ reporting $\mathrm{TiB}_{\mathrm{x}}$ films with $1.62 \leq x \leq 1.97$, demonstrating hardnesses in the range of 39-45 GPa, which the authors attributed to film densification. The films also showed superior fracture strength compared to corresponding overstoichiometric $\mathrm{TiB}_{\mathrm{x}}$ films. The lack of reports on similar topics is primarily due to the difficulty of depositing understoichiometric $\mathrm{TiB}_{\mathrm{x}}$ films with $\mathrm{DCMS}$, one of the reasons being the difference in the angular distribution of sputtered material between lighter and heavier material (further discussed in Chapter 3).

The understanding of synthesis, microstructure, and properties of understoichiometric $\mathrm{TiB}_{\mathrm{x}}$ films has been expanded upon in this thesis. In Paper I, I present synthesis of both under- and overstoichiometric $\operatorname{TiB}_{\mathrm{x}}$ with $1.43 \leq x \leq 2.70$, to facilitate a comparison on the role of $\mathrm{B}$ content on microstructure, mechanical, electrical, and thermal properties. To achieve this wide span of compositions, both HiPIMS and DCMS were used. The former to grow understoichiometric films and the latter to grow overstoichiometric films. I showed that understoichiometric films could achieve, and even surpass, the mechanical properties seen in the corresponding

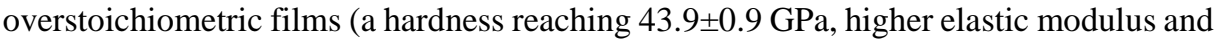
higher fracture toughness). The residual stress was also mapped, showing compressive stress in under- and overstoichiometric films, while films closer to stoichiometric composition exhibited tensile stress. Comparisons of both electrical and thermal conductivity were also done and presented. In addition, I show that deficiency of B is found to be accommodated by planar defects with Ti-rich stacking faults while tissue phase was absent. Figure 5 shows how the stacking faults are seen along the [0001] zone axis with plan-view HAADF-HRSTEM, more thoroughly discussed in Paper VI (not included in the thesis). The oxidation kinetics of the films in Paper I is investigated in Paper II, showing that understoichiometric films have significantly better oxidation 

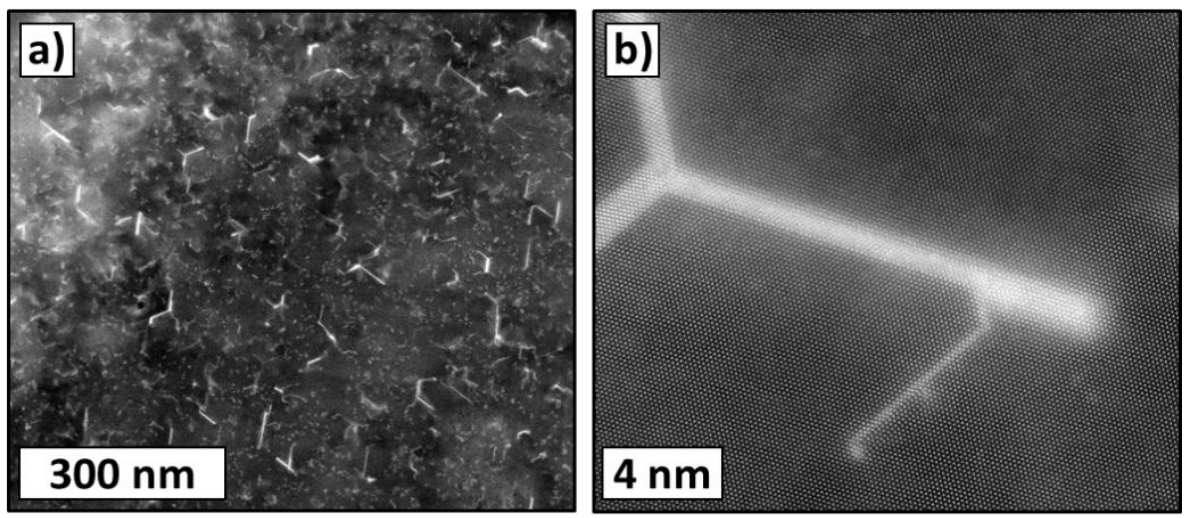

Figure 5 - Plan-view HAADF-HRSTEM images from $\mathrm{TiB}_{1.9}$ thin film along [0001] zone axis. With an overview seen in a) and higher magnification in b) showing Ti-rich stacking faults.

resistance than the corresponding overstoichiometric films. All $\mathrm{TiB}_{\mathrm{x}}$ films appears to have linear oxidation rates strongly dependent on the B content.

\subsection{Titanium Aluminum Diboride}

In attempts to improve oxidation resistances for the $\mathrm{TiB}_{\mathrm{x}}$ diboride, alloying with $\mathrm{Al}$ is of high interest. Air annealing of Al-ion implanted $\mathrm{TiB}_{2}$ coatings at $650{ }^{\circ} \mathrm{C}$ have previously shown an improvement in oxidation resistance. ${ }^{60}$ However, the inclusion of Al greatly effects the otherwise desirable characteristics of $\mathrm{TiB}_{\mathrm{x}}$ films. Systematic investigations of the Ti-Al-B system is thus important to understand how to retain the mechanical properties seen in the pure $\mathrm{TiB}_{\mathrm{x}}$ system, while attaining the beneficial oxidation kinetics that $\mathrm{Al}$ offers.

Overstoichiometric $\mathrm{Ti}_{1-\mathrm{x}} \mathrm{Al}_{\mathrm{x}} \mathrm{B}_{2-\mathrm{y}}$ films have previously been deposited with dual magnetron sputtering from $\mathrm{TiB}_{2}$ and $\mathrm{AlB}_{2}$ targets, on an $\mathrm{Al}_{2} \mathrm{O}_{3}$ wafer, with $0.30 \leq x \leq$ 0.66 and $-0.07 \leq y \leq-1.22$, showing the dependence of hardness and microstructure on composition. ${ }^{20} \mathrm{Al}$-rich regions displayed dense conical columns growing along the substrate normal. These columns consisted of $\mathrm{Ti}$ - and $\mathrm{Al}$-rich partitioning regions with an interlacing B-rich tissue phase, more of the latter closer to the Al-rich regions. These regions also showed lower hardness, lower degree of crystallinity and a microstructure 
quite different from pure $\mathrm{TiB}_{\mathrm{x}}$. However, regions richer in $\mathrm{Ti}$ showed a mixture of the classical dense nanocolumnar $\mathrm{TiB}_{\mathrm{x}}$ structures and the same conical columns seen in the Al-rich region. Moreover, the Ti-rich region had higher B content and, naturally, more B-rich tissue phase in the grain boundaries than the Al-rich regions. The highest hardness value achieved for these compositions was found in the Ti-rich region at 28 $\mathrm{GPa}$, with a composition of $\sim \mathrm{Ti}_{0.70} \mathrm{Al}_{0.30} \mathrm{~B}_{3.22}$.

Expanding the range of $\mathrm{Ti}: \mathrm{Al}$ ratios in $\mathrm{Ti}_{1-\mathrm{x}} \mathrm{Al}_{\mathrm{x}} \mathrm{B}_{2-\mathrm{y}}$ coatings can be achieved by using DCMS and a segmented $\mathrm{TiB}_{2}-\mathrm{AlB}_{2}$ target in an industrial scale CemeCon deposition system. ${ }^{21}$ The experimental setup illustrated in Figure 6 shows a) the segmented target and b) the substrate holder, and it is the same as used in Paper III. This setup have previously realized films with compositions of $0.06 \leq x \leq 0.99$ and $0.92 \leq y \leq 0.30$, including close to pure $\mathrm{AlB}_{2}$ and pure $\mathrm{TiB}_{2}$ with only traces of $\mathrm{Ti}$ and $\mathrm{Al}$, respectively, in addition to over- and understoichiometric films with respect to $\mathrm{B}$ content. ${ }^{21}$ The Al-rich films were found to be amorphous, while the highest crystallinity

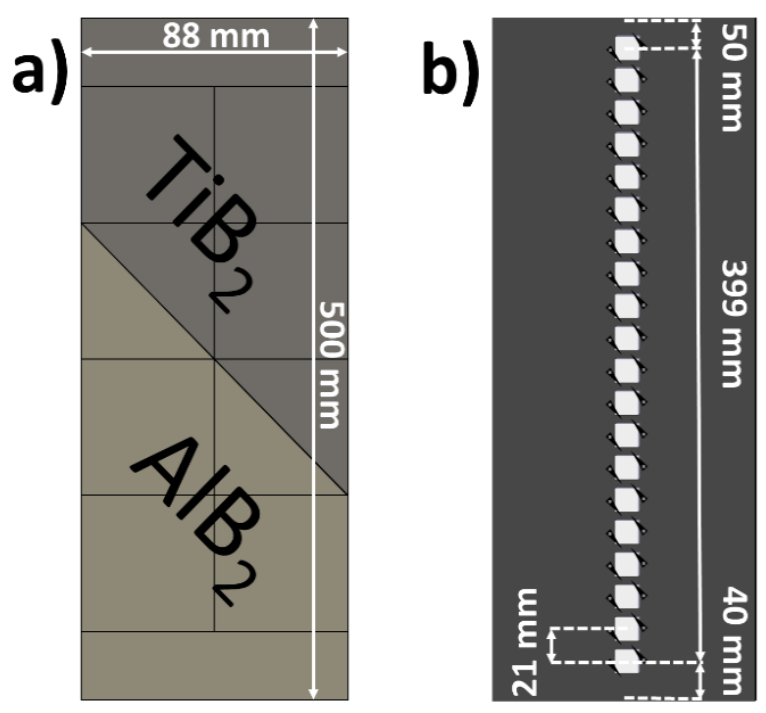

Figure 6 - Illustration of experimental setup in industrial CemeCon system showing dimensions of the a) segmented $\mathrm{TiB}_{2}-\mathrm{AlB}_{2}$ target and b) substrate-holder used. 
was found in Ti-rich films with roughly $10-20 \% \mathrm{Al}$, in line with previously observed trends. ${ }^{20}$ The highest hardness values reported were at $\sim 39 \mathrm{GPa}$ for $\mathrm{Ti}_{0.79} \mathrm{Al}_{0.21} \mathrm{~B}_{2.70 .}{ }^{21}$

Worth noting is the nature and the composition of the tissue phase in this ternary materials system. In $\mathrm{Ti}_{1-\mathrm{x}} \mathrm{Al}_{\mathrm{x}} \mathrm{B}_{2-\mathrm{y}}$ coatings, the tissue phase is present in both over- and understoichiometric films. ${ }^{20,}{ }^{21}$ In understoichiometric $\mathrm{Ti}_{1-\mathrm{x}} \mathrm{Al}_{\mathrm{x}} \mathrm{B}_{2-\mathrm{y}}$ coatings, the tissue phase consists of an $\mathrm{Al}-$ rich $\mathrm{Ti}_{\mathrm{k}} \mathrm{Al}_{\mathrm{l}} \mathrm{B}_{\mathrm{m}}$ tissue phase, ${ }^{17}$ showing that $\mathrm{Al}$ segregates to the grain boundaries in $\mathrm{B}$ deficient films. ${ }^{20} \mathrm{~A}$ similar trend has been seen in understoichiometric $\mathrm{Zr}_{1-\mathrm{x}} \mathrm{Ta}_{\mathrm{x}} \mathrm{B}_{\mathrm{y}}$ coatings, also there showing a Ta-rich $\mathrm{Zr}_{\mathrm{k}} \mathrm{Ta}_{1} \mathrm{~B}_{\mathrm{m}}$ tissue phase. ${ }^{37}$ These trends suggest that the composition of the boundary phases in $\mathrm{Ti}_{1-\mathrm{x}} \mathrm{Al}_{\mathrm{x}} \mathrm{B}_{2 \text { - }}$ y films is determined by the B content, which in turn restrains grain growth in the inplane direction. ${ }^{20}$ If there is excess $\mathrm{B}$, the tissue phase will only be comprised of $\mathrm{B}$. If there is a deficiency of $\mathrm{B}$, the tissue phase will be a metal-enriched mixture with traces of B.

A challenge with systematic investigations of the ternary metal diboride $\mathrm{Ti}_{1 \text { - }}$ ${ }_{x} \mathrm{Al}_{\mathrm{x}} \mathrm{B}_{\mathrm{y}}$ is the ability to fixate either $x$ or $y$, and thus, be able to carry out a comparative study where only one of these is changed. This can be circumvented, as shown in Paper III, by tuning several deposition parameters and utilizing many different depositions, essentially growing films and mapping the attainable compositional space so that it possible to isolate changes to either $x$ or $y$.

In doing so, I achieved several films with a fixed B:M ratio, varying just the Ti:Al ratio, and another set of films with a fixed Ti:Al ratio, varying just B:TM content. I compared $\mathrm{Ti}_{0.9} \mathrm{Al}_{0.1} \mathrm{~B}_{2-\mathrm{y}}$ films with $y=1.3,1.4$ and 1.9, and showed that the highest hardness, 46.2 $\pm 1.1 \mathrm{GPa}$, and best oxidation resistance are found in the most B deficient film, and that the oxidation rate is of parabolic type. I also showed that mechanical properties depend on the attained texture, while oxidation resistance does not show the same dependence. This was done by comparing two films with very similar compositions, but vastly different texture. In addition, the mechanical properties were shown to depend on $\mathrm{Al}$ content in $\mathrm{Ti}_{\mathrm{x}-1} \mathrm{Al}_{\mathrm{x}} \mathrm{B}_{1.3}$ films, with $x=0.1,0.4$ and 0.7 . This has 

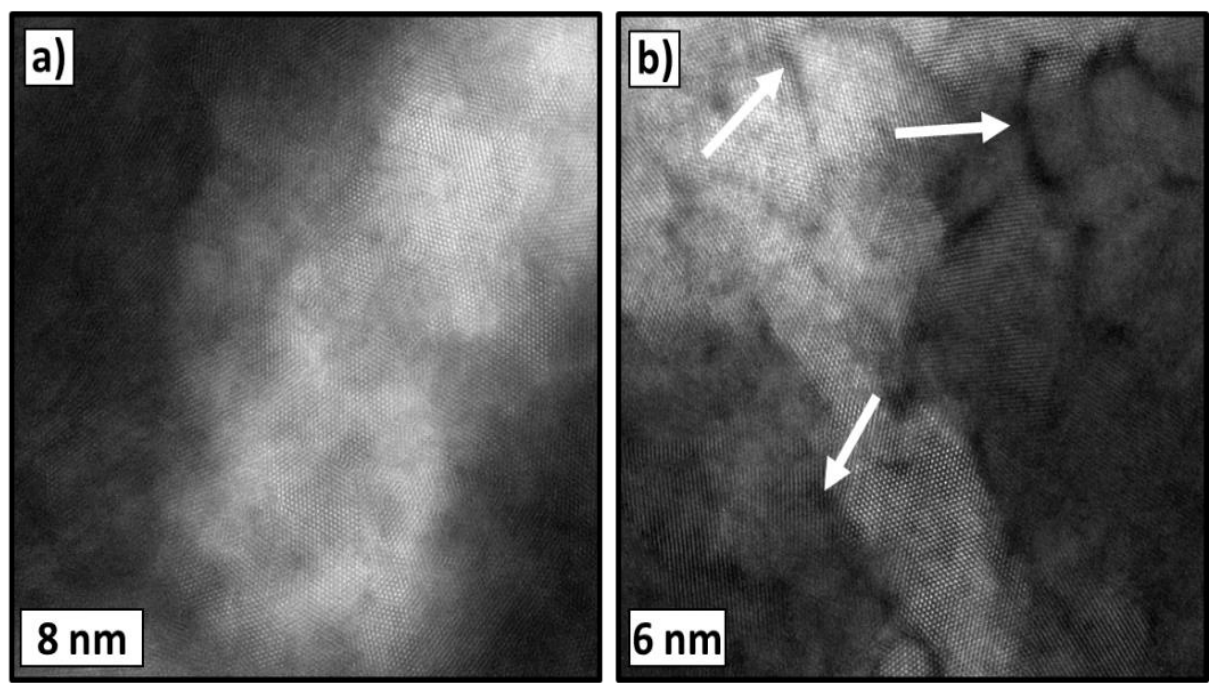

Figure 7 - plan-view STEM of a) $\mathrm{Ti}_{0.9} \mathrm{Al}_{0.1} \mathrm{~B}_{1.3}$ showing no apparent boundary phase and b) $\mathrm{Ti}_{0.9} \mathrm{Al}_{0.1} \mathrm{~B}_{1.9}$ showing boundary phase, indicated by arrows, consisting of $\mathrm{B}$-rich $\mathrm{Ti}_{\mathrm{x}-1} \mathrm{Al}_{\mathrm{x}} \mathrm{B}_{2-\mathrm{y}}$ tissue phase.

been suggested but never shown, as the B content has always been varying as the Ti:Al ratio changes. These results show that $\mathrm{Ti}_{1-\mathrm{x}} \mathrm{Al}_{\mathrm{x}} \mathrm{B}_{2-\mathrm{y}}$ coatings can attain the same mechanical properties as pure $\mathrm{TiB}_{\mathrm{x}}$, while gaining superior oxidation kinetics with a parabolic oxidation rate. Plan-view STEM can be seen in Figure 7 a) for $\mathrm{Ti}_{0.9} \mathrm{Al}_{0.1} \mathrm{~B}_{1.3}$, showing no apparent boundary phases, and b) for $\mathrm{Ti}_{0.9} \mathrm{Al}_{0.1} \mathrm{~B}_{1.9}$, showing a boundary phase consisting of $\mathrm{B}$-rich $\mathrm{Ti}_{\mathrm{k}} \mathrm{Al}_{1} \mathrm{~B}_{\mathrm{m}}$ tissue phase.

\subsection{Chromium Diboride}

Chromium diboride, $\mathrm{CrB}_{\mathrm{x}}$, is a less studied ceramic compound in the $\mathrm{TM}$ diboride family. In bulk it shows impressive characteristics such as high melting point, good mechanical and thermal properties, with low thermal expansion coefficient. ${ }^{61}$ Most impressive properties can be found in its high corrosion, and oxidation resistance. ${ }^{19,} 62$

$\mathrm{CrB}_{\mathrm{x}}$ film texture is known to affect both corrosive and wear resistance, ${ }^{63}$ with crystalline $\mathrm{CrB}_{\mathrm{x}}$ films with a preferred (001) phase orientation showing better results than (101). Magnetron sputtered $\mathrm{CrB}_{\mathrm{x}}$ films show that corrosive resistance for (001) oriented films is superior, with no localized corrosion, while (101) oriented films exhibit 
a corrosion-induced fracturing phenomenon resulting in corrosion of the substrate (AISI 316L) ${ }^{64}$ Both the (001) and (101) films show superficial plastic deformation. Films with (101) texture is more prone to wear-induced coating fracturing. In comparison, $\mathrm{TiB}_{\mathrm{x}}$ films show clear plastic deformation with (100) and (110) being the dominant slip planes. ${ }^{65}$

The control of texture is thus of high interest in order to achieve the best possible corrosive and wear resistance. A handful of investigations have been done to improve the understanding of the influence of DCMS growth parameters on these properties. Lower deposition temperatures $\left(<200{ }^{\circ} \mathrm{C}\right)$ favor the formation of a (101) phase orientation, intermediate temperatures $\left(200{ }^{\circ} \mathrm{C}\right.$ to $\left.300{ }^{\circ} \mathrm{C}\right)$ appear to favor the formation of a crystalline, underdense, glassy texture with a mixture of (101) and (001) phase orientation, while higher temperatures $\left(>300{ }^{\circ} \mathrm{C}\right)$ shifts the preferred orientation (PO) to (001) with a dense nanocolumnar structure. ${ }^{64}$ The PO also depends on the deposition pressure, showing a conversion from (001) to (101) upon increasing the deposition pressure from 2 mTorr to 5 mTorr, respectively, when deposited below $200{ }^{\circ} \mathrm{C} .66$

This transition in texture and microstructure is partly linked to the temperaturedependent adatom surface mobility. ${ }^{67,68}$ Simplified, and more thoroughly explained in literature ${ }^{69}$ the mobility of an adatom on the growing coating at low deposition temperatures is low. The likelihood of adatom rearrangement is thus less probable, and this can result in the formation of imperfect $\mathrm{CrB}_{\mathrm{x}}$ crystals with more defects. In $\mathrm{CrB}_{\mathrm{x}}$ at lower temperatures, the PO of (101) texture is mostly due to the high surface energy plane compared to (001), making it favorable for an adatom to diffuse from (001) to (101) planes. Higher adatom mobility results in larger probability for migration on the surface, promoting growth of planes with the lowest surface energy ${ }^{69} \operatorname{In} \mathrm{CrB}_{\mathrm{x}}$, this leads results in the formation of densely $\mathrm{CrB}_{\mathrm{x}}(001)$ films with less defects. ${ }^{19}$

Hardness in $\mathrm{CrB}_{\mathrm{x}}$ show microstructural dependences. For example, the increase of growth temperature, of crystalline $\mathrm{CrB}_{\mathrm{x}}$ with (001) PO, from 200 to $400{ }^{\circ} \mathrm{C}$ led to an 
increase of hardness from 44 to $51 \mathrm{GPa} .{ }^{63,64}$ Going from the mixture of (101) and (001) to predominantly (001) oriented films also significantly increases the elastic modulus. ${ }^{64}$

$\mathrm{CrB}_{\mathrm{x}}$ films with $x \leq 1.5$ has been deposited using a target with $x=1.5$. The resulting films showed a (101) texture with columnar microstructures interlaced by B-rich tissue phase in the grain boundaries. Naturally, with the absence the favorable properties observed in corresponding (001) textured $\mathrm{CrB}_{\mathrm{x}}$ films. This could possibly be explained by the pressure and temperature used, 3 mTorr and $300{ }^{\circ} \mathrm{C}$, parameters bordering on those that favor (101) texture formation. However, since most preceding studies failed to report the composition, and their respective properties as a function of that composition, it is not possible to determine if the resulting properties were due to film composition or texture and microstructure.

Investigations show that deposited $\mathrm{CrB}_{\mathrm{x}}$ films have a similar composition as the sputtered target, ${ }^{70,71}$ and exemplified by the $\mathrm{CrB}_{\mathrm{x}}$ deposited films ranging from $1.90 \leq$ $x \leq 2.08$ when using a stoichiometric $\mathrm{CrB}_{2}$ target in Paper IV. This is quite different compared to the $\mathrm{TiB}_{\mathrm{x}}$ films deposited under similar conditions, which generally generates $\mathrm{TiB}_{\mathrm{x}}$ films ranging from $2.0 \leq x \leq 3.3$ if a stoichiometric $\mathrm{TiB}_{2}$ target is used. ${ }^{31}$, 49, 72-74 In Paper IV we found that the film composition has no apparent dependence on substrate temperature in the ranges investigated, $500{ }^{\circ} \mathrm{C}$ and $900{ }^{\circ} \mathrm{C}$, and only a weak dependence on pressure for the samples deposited at higher temperature, with a reduction in $\mathrm{B}$ with increasing pressure, from 5 mTorr to $20 \mathrm{mT}$ Torr. At the lower temperature, the films exhibit a (001) fiber texture when grown at $5 \mathrm{mTorr}$, and more randomly oriented grains at $20 \mathrm{mTorr}$, At $900^{\circ} \mathrm{C}$, the $\mathrm{CrBx}$ films grow epitaxially to $\mathrm{Al2O}(001)$ substrates with high crystalline quality. We show that B deficiency is presented in understoichiometric $\mathrm{CrB}_{\mathrm{x}}, \mathrm{CrB}_{1.90}$, as $\mathrm{Cr}$-rich stacking faults, similar to the Ti-rich stacking faults in understoichiometric $\mathrm{TiB}_{\mathrm{x}}$ films, ${ }^{75,76}$ see Figure 8 a). For overstoichiometric $\mathrm{CrB}_{\mathrm{x}}, \mathrm{CrB}_{2.08}$, large B-rich inclusions could be observed, seen as dark regions in Figure 8 b). In contrast with what is observed in overstoichiometric $\mathrm{TiB}_{\mathrm{x}}$ films where a B-rich tissue phase interlacing columnar $\mathrm{TiB}_{2}$ structures is formed. 


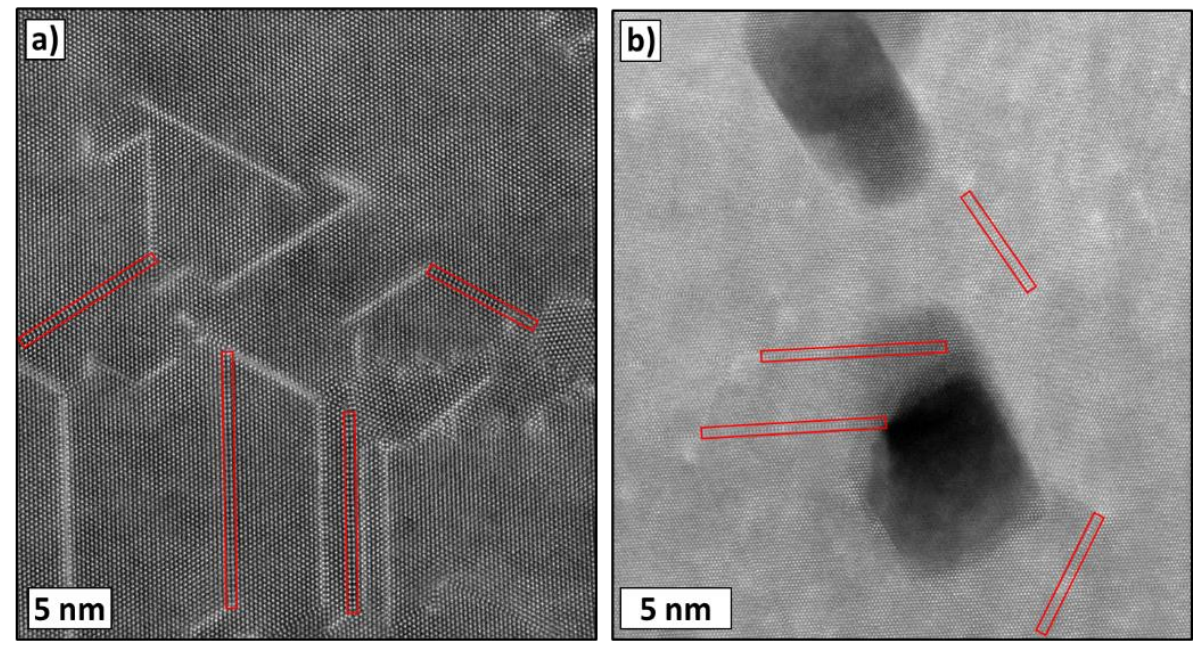

Figure 8 - HAADF-HRSTEM images of $\mathrm{CrB}_{\mathrm{x}}$ films showing a) Cr-rich stacking faults as high contrast lines in $\mathrm{CrB}_{1.90}$ and b) B-rich inclusions as dark regions in $\mathrm{CrB}_{2.08}$. Rectangles indicate ordinary planar defects observed in both samples.

Both the over- and understoichiometric $\mathrm{CrB}_{\mathrm{x}}$ films showed ordinary line faults, as indicated by rectangles in Figure 8. 


\section{THIN FILM SYNTHESIS}

\subsection{Thin Film Deposition Techniques}

Thin layers of materials with a thickness ranging from a few angstroms to several microns are usually referred to as thin films. Synthesis of these films can be divided into two broad categories, Chemical Vapor Deposition (CVD) and Physical Vapor Deposition (PVD). ${ }^{77,78}$ Briefly described, CVD is based on a volatile fluid precursor that causes a chemical change on a substrate and/or surface, leaving a chemically deposited coating, while PVD is material typically going from a condensed state in a source, to plasma and back to condensed state on a substrate and/or surface. The more common processes of PVD are arc evaporation and sputtering. ${ }^{79,80}$

\subsection{Sputtering}

Sputtering is a mechanism of ejecting microscopic particles from a solid or liquid surface by transferring momentum of incoming particles, plasma or gas to surface particles. Similar to how one might visualize the impact of an asteroid and the ejection of large amounts of debris into the atmosphere following its collision. This sputtering phenomena can be used in a controlled environment to purposefully transfer material from one surface to another at a precise rate, ${ }^{81}$ and was first discovered in 1852 by Grove and later developed as a thin film deposition technique in 1920 by Langmuir. ${ }^{82,83}$ The process takes place in a vacuum chamber with a sputtering target and a substrate. To eject material from a surface, a chemically inert gas is introduced into the chamber. This can be $\mathrm{Kr}$, Ne or Ar with the latter being the most commonly used.

The magnetron uses a direct current (DC), pulsed DC or a radio frequency (RF) power source depending on the cathode material properties and/or requirements on the film deposition. DC is the most frequently used power source for electrically conductive targets. It is easy to control with a lower power consumption. Limitations of DC sputtering are consequently incompatible with dielectric targets, and non-conductive materials. This is due to an accumulation of positive ions on the target surface that, over time, prohibits the discharge of atoms (i.e. the sputtering process/phenomenon). Several 
techniques to neutralize the target exists. Pulsed DC sputtering cycle power spikes to the target and helps preventing dielectric charge build-up, while RF sputtering alternates the potential to avoid charge build up.

The inert gas becomes positively ionized and starts to accelerate towards the target with an applied negative potential. If the kinetic energy is high enough, the ions will sputter away material from the target. The sputtered species is then transported through the chamber and are subsequently deposited on the substrate. Worth noting is that the ion interaction on the target surface gives rise to secondary electrons, which in turn is accelerated away from the negatively biased target. These electrons then assist in sustaining the so called discharge.

For the actual thin film growth, the substrate temperature is typically a very important parameter. The heating process in sputter deposition is usually facilitated by a substrate heater mounted in the vacuum chamber, behind the substrate holder. But there are more contributing factors for the film formation: the kinetic energy of the incident material and the flux, providing energy for the condensation on the substrate surface. ${ }^{84}$ The effect of temperature is discussed more in the concluding chapter in growth methods.

\subsection{Magnetron Sputtering}

Since the discharge is primarily sustained with the secondary electrons ejected from the surface, "Penning" proposed a technique that surrounds the target in a magnetic field with the help of magnets behind the cathode. 85 This facilitates capturing and trapping of the ejected secondary electrons and thus to further enhance the discharge and help to sustain it. This also directly improves the overall quality of the films by limiting the electron bombardment on the substrate, something that can cause overheating and/or damage of the films. Using a DC power-source for magnetron sputtering (DCMS) is the most basic and commonly used sputtering technique for PVD metal deposition. An illustration of the sputtering processes can be seen in Figure 9. 


\subsection{High Power Impulse Magnetron Sputtering}

High-Power Impulse Magnetron Sputtering (HiPIMS) is a more recent but already wellestablished sputtering technique that utilizes pulsed power on the target in a unipolar fashion, as demonstrated by Kouznetsov. ${ }^{86}$ They replaced the sputtering power supply in a conventional DCMS setup, and together with an ability of directing the sputtering gas, they showed higher degrees of ionization of the sputtered material and void-free trench filling in the resulting film. The general idea of HiPIMS is to utilize high-power densities in short pulses, on the order of tens of microseconds at low duty cycles (on/off ratio, d.c.). In Figure 10 a graph can be seen with data collected from an oscilloscope connected to a power supply, a substrate bias controller, and a pulse generator. The sputtering targets average power, $P_{T}$, is a function of the target voltage pulse, $V_{p}$, and current pulse, $I_{p}$, and is tuned with the power supply displayed by the black and red lines in Figure 10, respectively. The substrate bias voltage, $V_{b}$, can also be pulsed, as

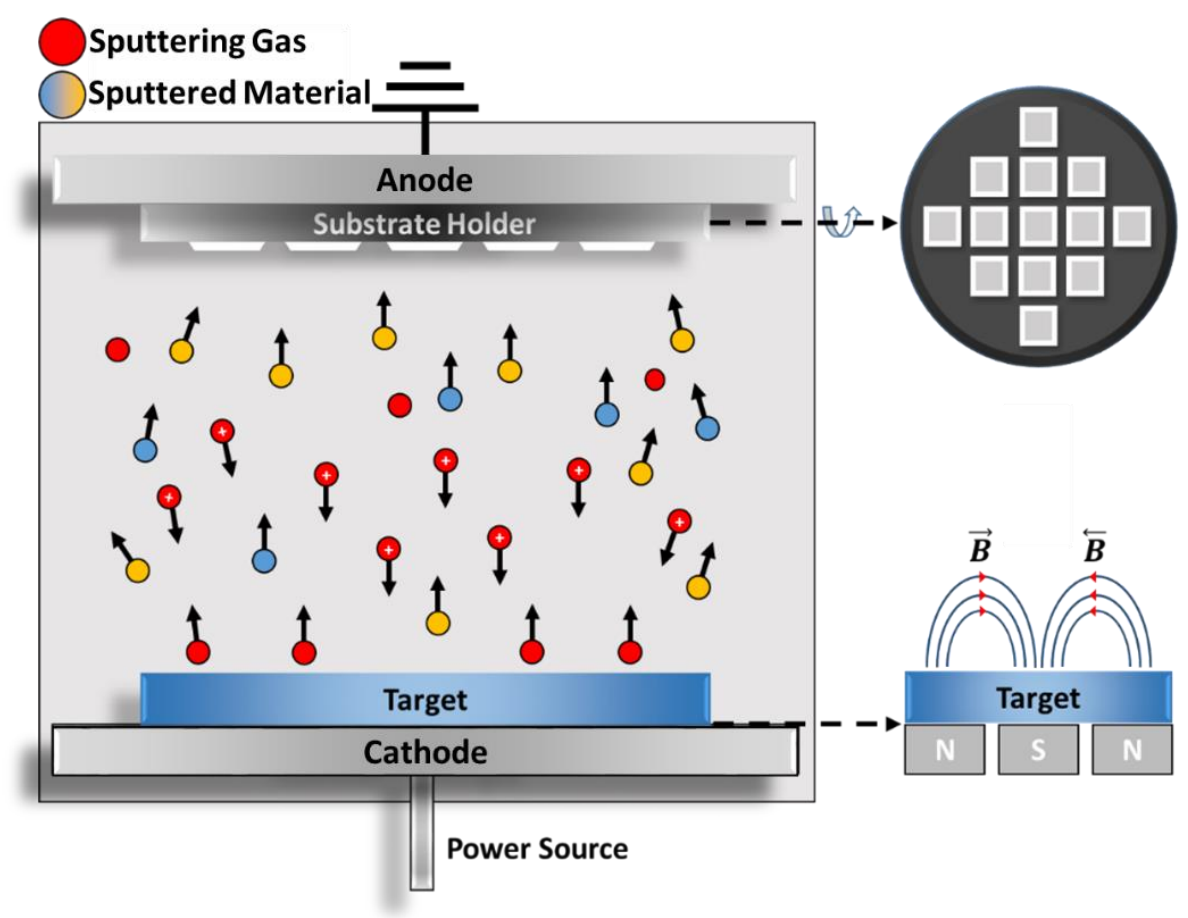

Figure 9 - Illustration of a DCMS system, showing the deposition chamber and a schematic of the sputtering process. 
illustrated by the blue line. The pulse, $t_{o n}$, is controlled by the pulse generator which adds several degrees of tunability. In the example in Figure 10, $\mathrm{t}_{\mathrm{on}}$ is set at $50 \mu \mathrm{s}$ with $V_{p}$ of $500 \mathrm{~V}$ and $I_{p}$ of $40 \mathrm{~A}$, with $V_{b}$ of $20 \mathrm{~V}$ for a duration of $100 \mu$ s. The frequency, $\mathrm{f}_{\mathrm{p}, \mathrm{b}}$, in this example was set to $100 \mathrm{~Hz}$, resulting in a $0.5 \%$ d.c..

In DCMS, the attainable deposition parameter range is often limited to different substrate bias modes and average power densities (as a function of voltage and current), whereas in HiPIMS the same flexibility is accessible, in addition to a variation of $t_{o n}, f_{p}$ and $P_{T}$, all affecting the film deposition. ${ }^{73,87}$ In HiPIMS, the power densities range from several hundred $\mathrm{Wcm}^{-2}$ to $\mathrm{kWcm}^{-2}$ within the pulse. This allows instant power densities several magnitudes larger than conventional DCMS, which utilizes a constant discharge power. ${ }^{88,89}$ As a result, the plasma density varies greatly, and in DCMS and HiPIMS we find densities $n$ the order of $10^{14}-10^{16} \mathrm{~m}^{-3}$ and $10^{17}-10^{18} \mathrm{~m}^{-3}$ respectively. ${ }^{90,91}$ The high plasma density in HiPIMS is accompanied by a higher degree of ionization for both gas and sputtered material. Several reports show that this enables improved control of film quality, microstructure, composition, and properties for a wide range of material systems, such as, Ta deposited on $\mathrm{SiC}, \mathrm{ZnO}, \mathrm{CrN}$ and $\mathrm{TiO}_{2} \cdot{ }^{92-101}$

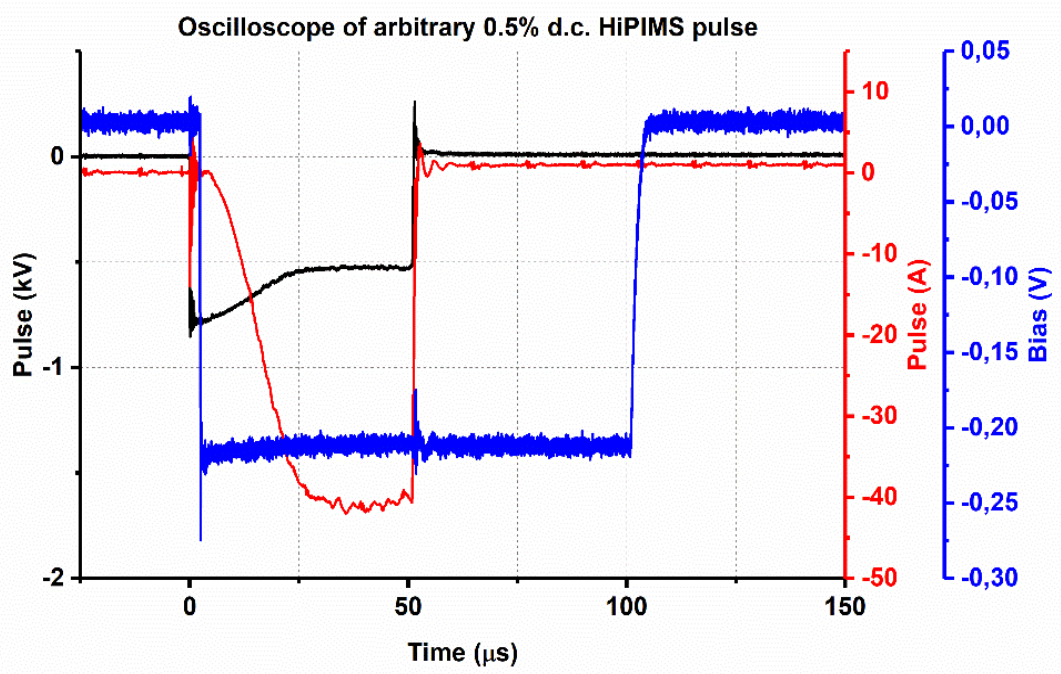

Figure 10 - Typical oscilloscope graph of a $0.5 \%$ d.c. HiPIMS pulse set at a $V_{p}$ of $500 \mathrm{~V}$ and a $I_{p}$ of $40 \mathrm{~A}$, using a overlapping and extended $V_{b}$ of $20 \mathrm{~V}$ for the duration of for $100 \mu \mathrm{s}$. 
A tangible similarity between DCMS and HiPIMS depositions is the importance of gas pressure (generally Ar), $p_{A r}$, and substrate temperature, $T_{s}$. Still, there are major differences in film composition from the two techniques even though the same $p_{A r}$ and $T_{s}$ are used. ${ }^{73}$ One of the major differences between these methods is the plasma ignition. For DCMS this essentially only occurs upon activation, due to the continuous discharge, while for HiPIMS the plasma ignition occurs several hundred times each second, as dictated by the $f_{p}$. This alone significantly changes the nature and order of how the sputtered material arrives at the substrate surface, in particular for sputtering from a compound target. 


\section{THIN FILM CHARACTERIZATION TECHNIQUES}

Several techniques were used to characterize the materials, and this chapter briefly describes the techniques and what information they can provide.

\subsection{X-ray Diffraction (XRD)}

$\mathrm{XRD}$ is a widely used analytical technique for identification and quantitative determination of atomic structures in solid materials and powders. ${ }^{102}$ It is versatile, nondestructive and does not require extensive sample preparation. The scanning procedure can take between mere minutes to multiple hours depending on the desired quality and range of the diffractogram. X-rays, a form of electromagnetic radiation, is generated when electrically charged particles with large enough energies are rapidly accelerated or decelerated. The X-rays are generated by electrons, originating from a heated filament, bombarding a target at potentials ranging between $5-50 \mathrm{KeV}$. Most of the electrons striking the targets lose energy to heat and less than $1 \%$ of the energy is transformed into X-rays. The technique utilizes these X-rays by analyzing the scattering by atoms on a sample. At certain incident angles (theta, $\theta$ ), constructive interference will occur according to Bragg's Law, see Equation (1). ${ }^{103}$

$$
n \lambda=2 d \sin (\theta)
$$

Where $n$ is an integer, $\lambda$ the wavelength of the X-rays, $d$ the spacing between layers of atoms and $\theta$ the angle between incident beam and the crystal surface. Bragg's law simply relates wavelengths of electromagnetic radiation to diffraction angle and lattice spacing of the sample. See Figure 11 for illustration. 


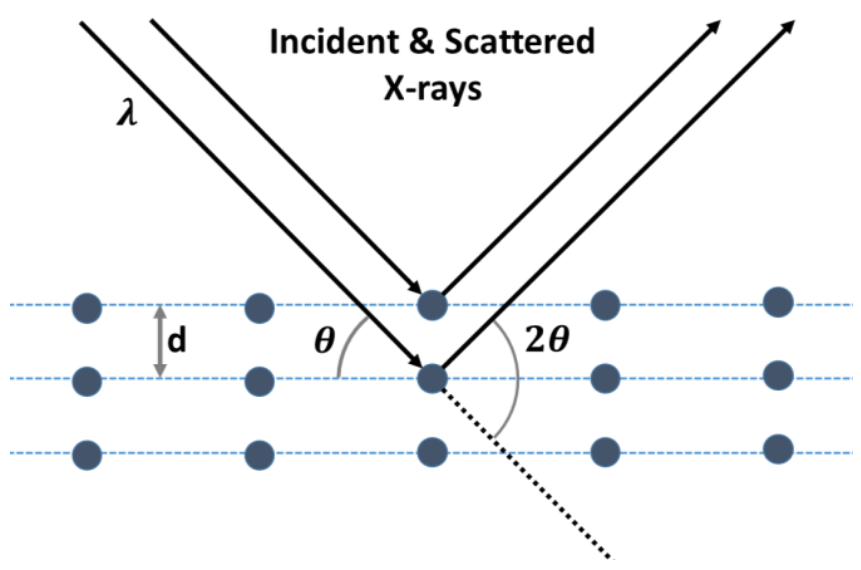

Figure 11 - Simplified schematic of X-ray diffraction with the wavelength $\lambda$, incident and scattered angle, $\theta-2 \theta$, and plane-spacing, $d$.

The diffracted X-rays are further processed by being detected and counted in a set range of $2 \theta$ angles. Conversion of the diffraction peaks to $d$ spacing allows characterization of the sample due to the unique set of $d$ spacing each and every crystalline material has. When working with powder it is important to check all possible diffraction directions of the lattice, this is due to the random orientation of the grains in the sample. When working with thin films it is important to align the optics with respect to the substrate. Typical XRD graph can be seen in Figure 12, where several diffractograms of the material system $\mathrm{Ti}_{\mathrm{x}} \mathrm{Al}_{1-\mathrm{x}} \mathrm{B}_{\mathrm{y}}$ are stacked, and arranged according to the metal ratio, $x$. Included are also dashed lines of the expected diffraction angles for the crystal planes of the material. A powerful way of determining the present phases in any crystalline material. The equipment used for all XRD measurements were a PANalytical X'Pert powder diffractometer, with $\mathrm{Cu}$ source $(\lambda=1.54 \AA$ ). The optics utilized was a PANalytical specific optical module, a graded Bragg-Brentano HD. 


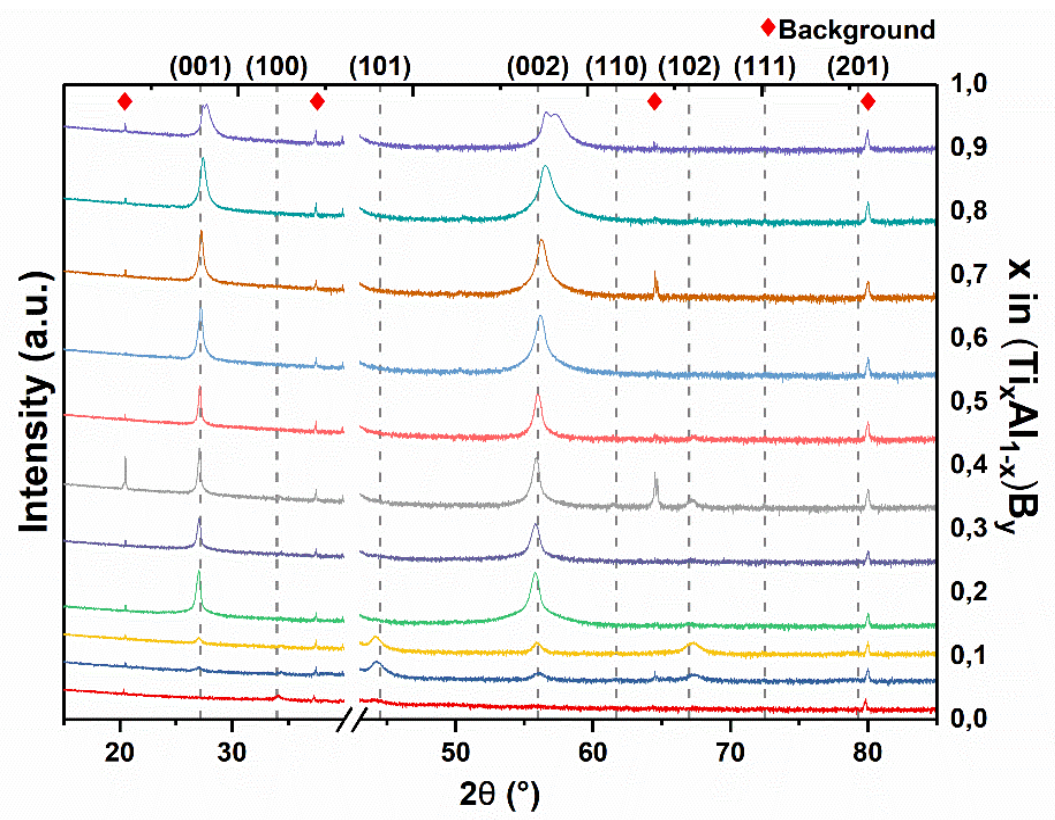

Figure 12 - Typical graph of several stacked X-ray diffractograms for the material system $\mathrm{Ti}_{\mathrm{x}} \mathrm{Al}_{\mathrm{x}-1} \mathrm{~B}_{\mathrm{y}}$ plotted as a function of diffraction-angle, $2 \theta$, and metal ratios, $x$. The dashed lines indicate reference lines for planes of pure $\mathrm{TiB}_{2}$ and squares the background noise.

\subsection{Scanning Electron Microscope (SEM)}

SEM is a technique used for topographical surface imaging by using a focused beam of electrons on a conducting surface. ${ }^{104}$ The topography is scanned by detecting secondary electrons from the sample surface. This process is analogous with the reflective mode of a Light Optical Microscope (LOM) however, the use of electrons increases the resolution and depth of field relative to that of an LOM where photons are used. This is due to the difference in operating wavelengths between electrons and photons. Limitations due to photon diffraction, fineness of lenses and mirrors in LOM limits resolution to approximately $0.2 \mu \mathrm{m}$ whereas SEM is only limited by the wavelength of the electrons, the electron-optical devices that produce the electron beam and the interaction volume. This gives SEM a resolution around $10 \mathrm{~nm}$. This is more than enough to identify larger particles, get good topographical imaging and cross-sectional views to determine film-thickness, as shown in Figure 13. This image shows a $\mathrm{TiB}_{2.2}$ 

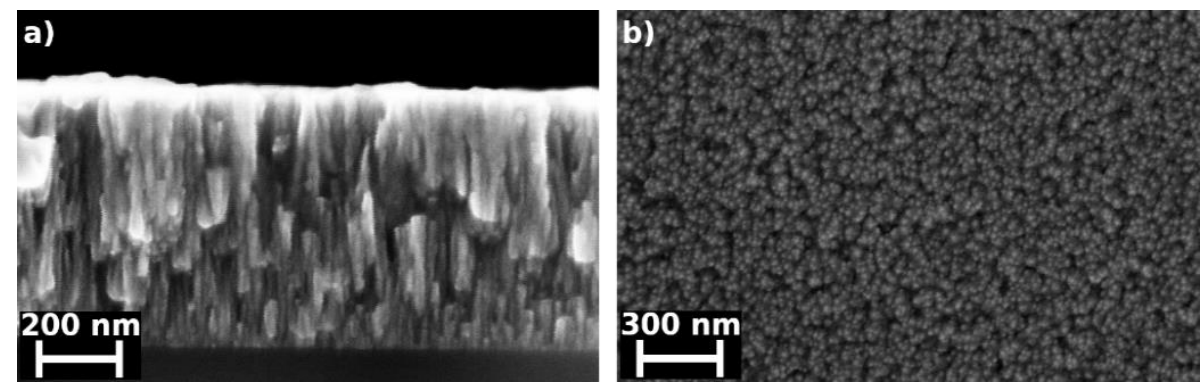

Figure 13 - SEM image of a $\mathrm{TiB}_{2.2}$ thin film showing a) clear nanocolumnar $\mathrm{TiB}_{2}$ structures as seen from cross-view and b) top-view.

film that has been split and investigated with SEM from a) cross-view and b) top-view, showing the characteristic nanocolumnar $\mathrm{TiB}_{2}$ structure. For this work a SEM LEO 1550 Gemini was used with an acceleration voltage ranging between 5-20 keV.

\subsection{Transmission Electron Microscopy (TEM)}

TEM is a technique used to obtain atomic resolution information by transmission of electrons, analogous to transmission mode in LOM, through an ultra-thin sample $(<50$ $\mathrm{nm}) .{ }^{104}$ TEM operates at a resolution of $<1 \mathrm{~nm}$ and can provide atomically resolved images of materials. This technique together with electron diffraction is widely used to obtain crystallographic information from a sample. The scattering that occurs during transmission of electrons gives diffraction patterns in reciprocal space. This information is then processed to give a sample image in real space. The atomic resolution is achieved

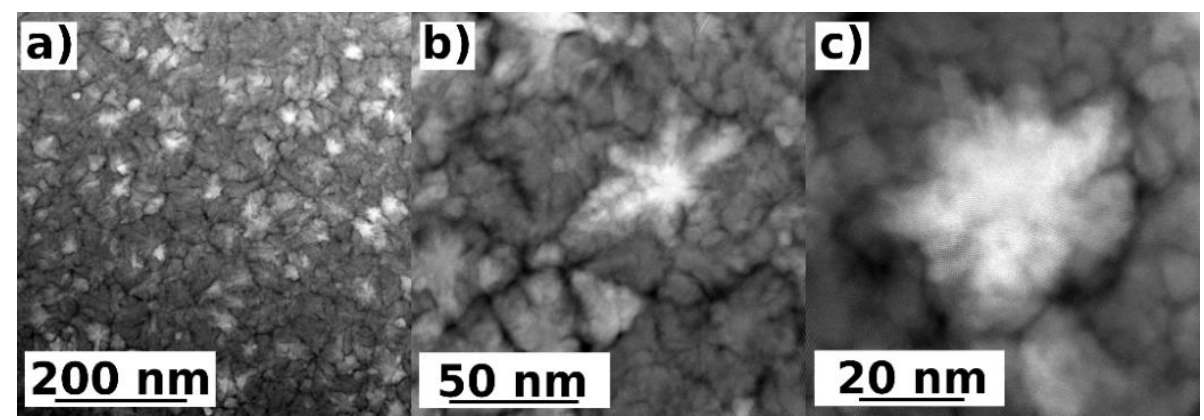

Figure 14 - plan-view HRSTEM of an overstoichiometric $\mathrm{TiB}_{\mathrm{x}}$ film at different magnifications showing clear columnar structures with interlacing, darker regions, B-rich tissue phase. 
due to the wave-like behavior a beam of electrons exhibit, explained by the de Broglie Hypothesis. ${ }^{105}$ Scanning Transmission Electron Microscopy (STEM) is a conventional TEM with additional equipment (scanning coils, detectors and needed circuitry) used in combination with a high-angle detector for atomic-resolution images where contrast is directly related to the atomic number (z-contrast image). Example of a plan-view HRSTEM image of an overstoichiometric $\mathrm{TiB}_{\mathrm{x}}$ film can be seen in Figure 14.

Here the characteristic columnar $\mathrm{TiB}_{2}$ structure is present with an interlacing $\mathrm{B}$ rich tissue phase. High-angle annular dark-field imaging (HAADF) is a highly atomicnumber sensitive STEM technique which produces an annular dark-field image using electrons that have been incoherently scattered at very high angles, see Figure 16 a) showing atomic resolution of the laminated structure seen in the MAX phase $\mathrm{V}_{2} \mathrm{AlC}$ (from listed but not included Paper VIII). ${ }^{106-108}$

Selected Area Electron Diffraction (SAED) is a crystallographic experimental technique that can be also used be performed with a TEM. It is used to identify crystal structures and possible crystal defects. It works in a similar way as XRD, however, rather than selecting an area of a centimeter as seen in conventional XRD, SAED focuses on areas as small as several hundred nanometers, see example of SAED on $\mathrm{Ti}_{0.9} \mathrm{Al}_{0.1} \mathrm{~B}_{1.3}$
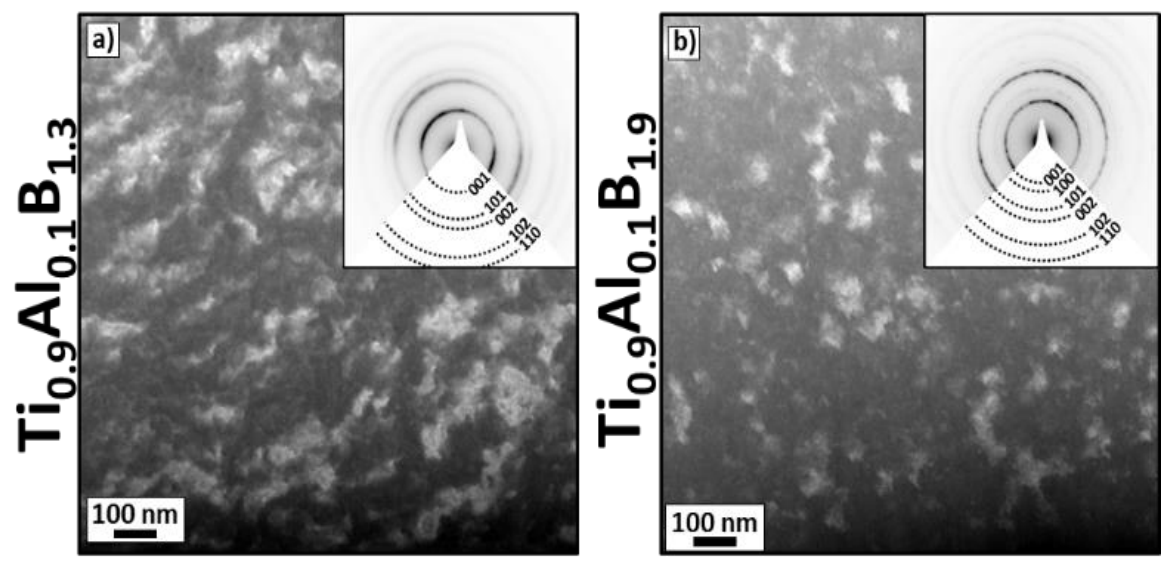

Figure 15 - Plan-view STEM and SAED of a) $\mathrm{Ti}_{0.9} \mathrm{Al}_{0.1} \mathrm{~B}_{1.3}$ and $\mathrm{b}$ ) $\mathrm{Ti}_{0.9} \mathrm{Al}_{0.1} \mathrm{~B}_{1.9}$. 
and $\mathrm{Ti}_{0.9} \mathrm{Al}_{0.1} \mathrm{~B}_{1.9}$ in Figure 15 a) and b), respectively. The SAED presents patterns of the reciprocal lattice, with lattice reflections seen as sharp diffraction spots. For this project high-resolution STEM (HRSTEM) was used to determine the composition and crystallographic orientation of the material. Microscopy was performed using the Linköping double corrected FEI Titan ${ }^{3} 60$ - 300 operated at $300 \mathrm{kV}$. STEM-HAADF imaging was performed by using a $21.5 \mathrm{mrad}$ convergence semi-angle, which provided sub-angstrom resolution probes with $\sim 60 \mathrm{pA}$ beam current and using an angular detection range of 46-200 mrad.

\subsection{Energy Dispersive X-Ray Spectroscopy (EDX)}

EDX is an analytical technique used for compositional analysis in samples. The method uses the fundamental principle that each element has its own unique atomic structure or electronic configuration. Atoms, at rest, contain unexcited electrons in electron shells bound to the nucleus. The electron shells of an atom have unique energy signatures. Electrons always strive to relax in shells closer to nucleus (ground state) and this fundamental property is what EDX takes advantage of. Electron holes in the inner shells are generated by exciting electrons residing there. The electron holes in the inner shells are then filled by electrons from the outer shells. The jump from a higher to a lower shell generates an X-ray. The intensity and energies of these X-rays is enough to characterize the unique atomic structure of an element thus, giving the elemental composition of the sample measured. The electrons used to excite ground state electrons require energies ranging between 5-20 KeV. Conveniently, EDX uses the same electron beam excitation principle as SEM and TEM. The detector can be mounted to these chambers and EDX can be carried out using the same electron gun, although at slightly higher energies (as mentioned above). In this project EDX was used in both SEM and TEM to investigate composition of various features seen in the material. In Figure 16 b) a typical application of EDX used in an SEM can be seen, showing that the laminated MAX phase $\mathrm{V}_{2} \mathrm{AlC}$ has traces of roughly 5 at. $\% \mathrm{Sc}$ in it (from listed but not included Paper VIII). 


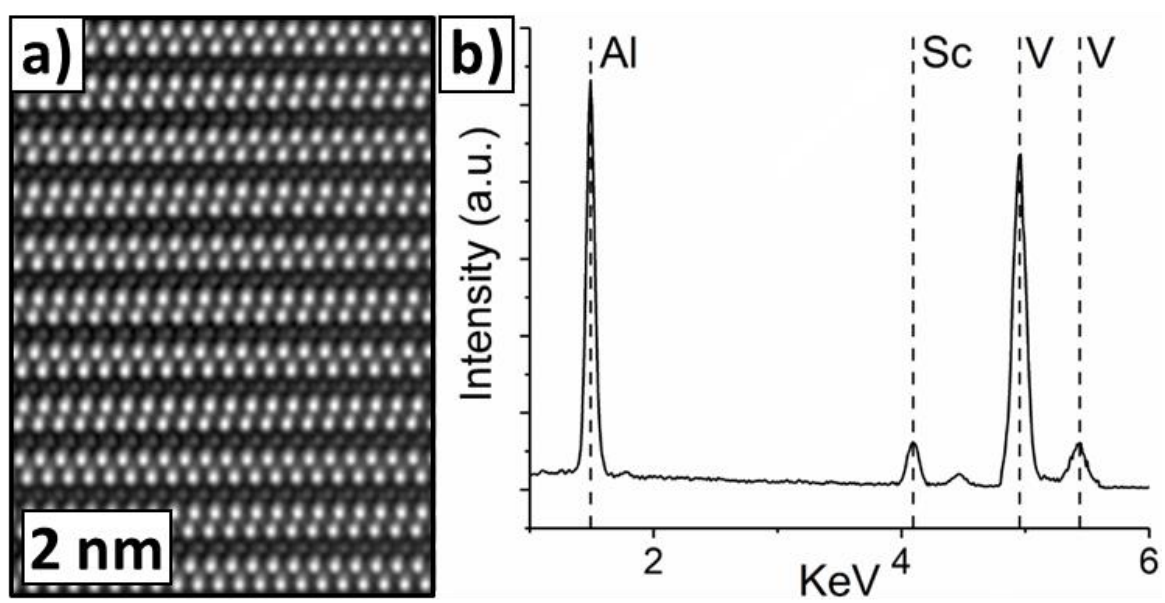

Figure 16 - a) HRSTEM-HAADF showing the laminated structure of the MAX phase $\mathrm{V}_{2} \mathrm{AlC}$ alloyed with Sc with b) corresponding EDX done by SEM showing particles with traces of Sc at roughly 5 at.\%.

\subsection{X-ray Photoelectron Spectroscopy (XPS)}

XPS is a surface-sensitive technique widely used for both quick and thorough compositional and chemical state analysis of both film and bulk surfaces. ${ }^{109}$ The quick sample preparation makes it very suitable for quick iterations in active research. The technique irradiates the sample surface with X-ray photons which in turn give rise to photon-emitted electrons through the photoelectric effect, see Equation (2), from the top-most 0-10 nm of the sample surface.

$$
E_{b}=h v-\left(E_{k}+\varphi\right)
$$

Where $E_{b}$ is the binding energy of the excited electron, $h v$ is the energy of the incoming photon, $E_{k}$ the kinetic energy of the detected photon and the work function $\varphi$. The photoelectrons are then collected and plotted in intensity as a function of binding energy. Through this we can get identification and chemical state of elements, relative composition in the irradiated region and valance band structure. In Figure 17 depth profiles of $\mathrm{TiB}_{1.43}$ and $\mathrm{TiB}_{2.20}$ films annealed in air at $400{ }^{\circ} \mathrm{C}$ for $48 \mathrm{~h}$, show a transition from oxide-rich layer to the as-deposited film (further discussed in Paper II). In this 

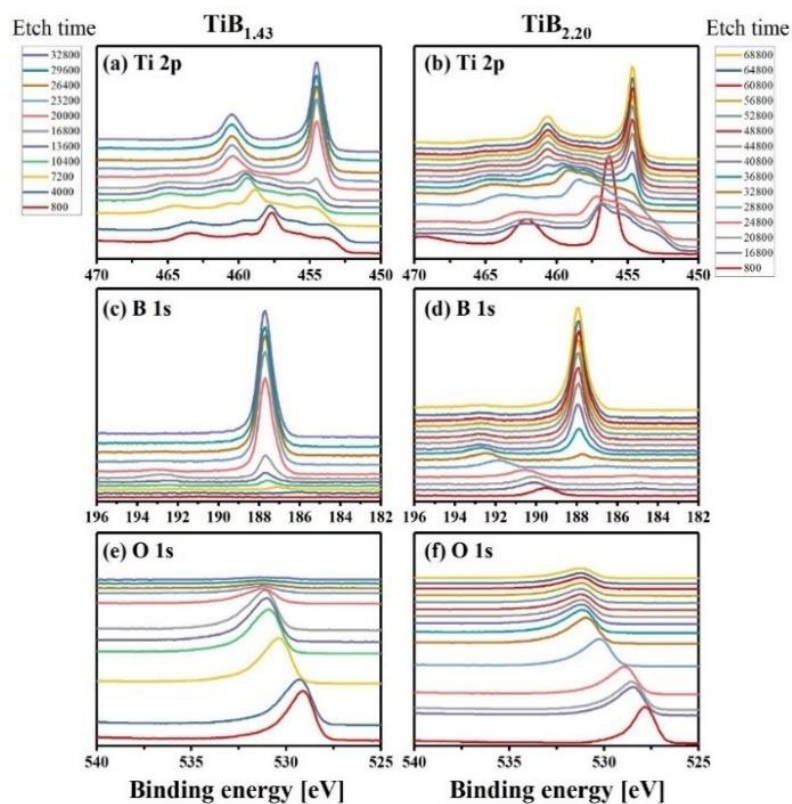

Figure 17 - XPS depth profiles of $\mathrm{TiB}_{1.43}$, left column, and $\mathrm{TiB}_{2.20}$, right column annealed in air at $400^{\circ} \mathrm{C}$ for $48 \mathrm{~h}$.

project, all analyses were performed in a Kratos Axis Ultra DLD instrument employing monochromatic $\mathrm{Al} \mathrm{K}_{\alpha}$ radiation $(\mathrm{h} v=1486.6 \mathrm{eV})$ and operating with a base pressure lower than $1.1 \times 10^{-9}$ Torr $\left(1.5 \times 10^{-7} \mathrm{~Pa}\right)$ during spectra acquisition. XPS depth profiles are acquired by sputter-etching with $0.5-\mathrm{keV} \mathrm{Ar}^{+}$ions incident at an angle of $70^{\circ}$ with respect to the sample surface normal. The low $\mathrm{Ar}^{+}$energy and shallow incidence angle are chosen in order to minimize the effect of sputtering damage on core level spectra. ${ }^{110,}$ 111

\subsection{Elastic Recoil Detection Analysis (ERDA)}

ERDA is an Ion Beam Analysis (IBA) technique used for compositional analysis and does so through mass and energy detection. ${ }^{12,}{ }^{113}$ Highly energetic ions are accelerated towards the sample surface and upon interaction cause an elastic nuclear reaction between ions originating from the beam and atoms of the surface. The sample ions are then recoiled towards a detector. The quantification depends on the species of the ions, scattering cross section area and change in energy of ions. The technique is good at 
detecting light elements going all the way down to $\mathrm{H}$, for which it was originally developed for.

\section{7. $\quad$ Rutherford Backscattering Spectrometry (RBS)}

RBS is, similarly to ERDA, an IBA technique that uses elastic collisions between highkinetic-energy particles from the beam and static particles on the sample surface. The difference in energy of a backscattered ion depends on scattering events with sample nuclei and scattering from sample electrons. The former depends on mass and atomic number of the atom and as such, the angle of ion scattering is determined by the element it interacts with. The latter is essentially described as the stopping power of electrons in the sample. A gradual loss of energy depends on the distance traveled within the sample. From this data a compositional analysis as well as a depth profile can be obtained. ${ }^{14-116}$

\subsection{Nanoindentation}

Nanoindentation is a technique used to determine hardness, $H$, and elastic modulus, $E$, of materials. It is non-destructive and can be used on both thin films and bulk samples. In summary, the technique operates an indenter made out of a diamond which is pressed onto the sample surface. The measurement consists of a relationship between the depth of penetration, prescribed load and type of deformation. Figure 18 a) illustrates the types of recovery, load and deformation. A typical indentation zone of a $\mathrm{TiB}_{2.70}$ thin film is shown in Figure 18 b). With good calibration a reliable value of $H$ and $E$ can be calculated using loading and unloading curves. Every sample was subjected to roughly 90 indentations with a Berkovich diamond tip within the load range of $0.1-13 \mathrm{mN}$. The load-displacement curves were analyzed by means of the Oliver and Pharr method. ${ }^{117}$ Subsequently, the elastic modulus of the films was calculated assuming a Poisson's ratio, $v$, of $0.15 .{ }^{118,119}$ Due to variations in the stoichiometry on the elastic constants of the materials, the upper and lower limits of $E$ were calculated with varying Poisson's ratios. ${ }^{120,121}$ After plotting $H$ and $E$ values as a function of penetration depth, only $H$ values from a fully developed plastic zone and yet unaffected by the substrate were 
a)
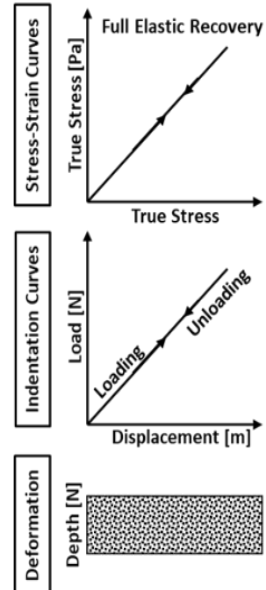
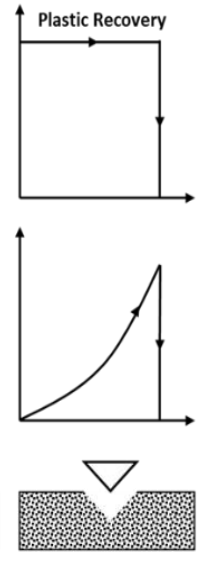

b)
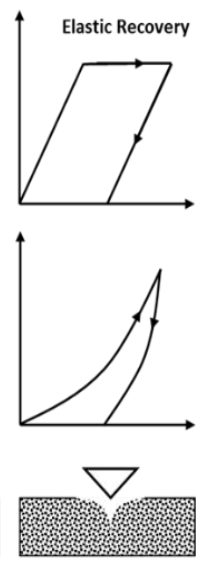

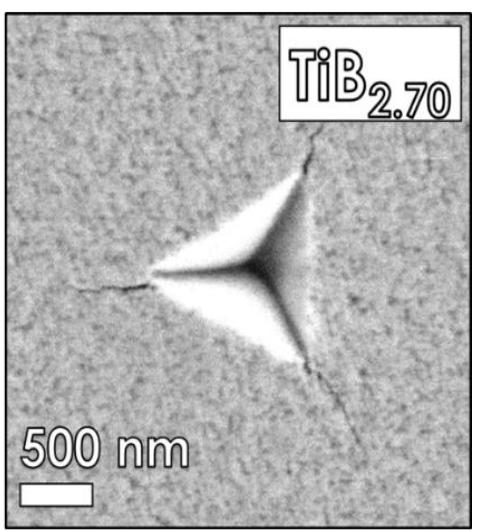

Figure 18 - Images illustrating a) theoretical stress-strain and indentation curves, and deformation as well as b) typical indentation zone from a $\mathrm{TiB}_{2.70}$ thin film.

considered film-only hardness, while a smooth curve was fitted to the $E$ values and subsequently extrapolated back to zero depth to obtain film-only elastic modulus. ${ }^{122}$

\subsection{Photo Thermal Radiometry (PTR)}

PTR is a technique used to determine thermophysical properties of thin films. It operates by illuminating the film surface with a laser beam at modulated intensities at fixed frequency range. Infrared radiation is then admitted from the surface of the film after heating. This radiation is measured via an infrared detector and compared with the frequency of the laser beam. A phase-lag will be measured between the sources and through this thermal characterization of films can be performed. $\mathrm{TiB}_{2}$ is transparent within the laser wavelength, so the absorption of a photon flux can no longer be considered as a surface phenomenon but must be discussed according to the optical properties of the film with respect to the thickness. For this reason, the films are capped with a metallic layer of approximately $100 \mathrm{~nm}$ which will have the role of a thermal and optical transducer. In other words, it will be considered at uniform temperature at each frequency and will perform the conversion of the photon flux into the heat flux. The 
measurement and analysis were done in collaboration with Institute I2M-University of Bordeaux, France. ${ }^{123,124}$ To determine the thermal conductivity and thermal resistance, an $\mathrm{Ar}^{+}$laser beam from a continuous heat source was modulated at an intensity in the range of 0.7 to $5 \mathrm{kHz}$ and was brought to an appropriate optical path through a set of mirrors close to the surface. The thermal response was measured with an infrared HgCdTe detector. The data is then modelled using either 1D heat transfer, which assumes perpendicular heat conduction, or a 2D model which also allows for heat conduction parallel to the film surface. The latter can suffice for films with thicknesses at or above $1 \mu \mathrm{m}$. 


\section{SUMMARY AND CONTRIBUTION TO THE FIELD}

\section{In Paper I, titled "Microstructure and Materials Properties of Understoichiometric}

TiB $_{x}$ Thin Films Grown by HiPIMS”, I synthesized understoichiometric $\mathrm{TiB}_{\mathrm{x}}$ using HiPIMS and compared microstructure, mechanical, thermal- and electrical properties with corresponding overstoichiometric $\mathrm{TiB}_{\mathrm{x}}$ films, deposited with DCMS. The microstructure of the overstoichiometric $\mathrm{TiB}_{\mathrm{x}}$ thin films has been known for a long time, where excess B is presented as a B-rich tissue phase in the grain boundaries between nanocolumnar $\mathrm{TiB}_{2}$ structures. However, the microstructure of understoichiometric $\mathrm{TiB}_{\mathrm{x}}$ was prior to this work unknown. Herein I showed that the B deficiency is presented by a complete absence of boundary phases between the columnar $\mathrm{TiB}_{2}$ structures. Instead, the columns contain planar defects with Ti-rich stacking faults. I showed that the understoichiometric films have mechanical properties that can match, and even surpass, the overstoichiometric counterpart. The residual stresses and fracture toughness were also investigated, the latter significantly higher for the understoichiometric films.

In the subsequent Paper II, titled "Improved Oxidation Properties from a Reduced B Content in Sputter-Deposited TiB $\mathbf{x}$ Thin Films", I further show the superiority of understoichiometric $\mathrm{TiB}_{\mathrm{x}}$ films by investigating the oxidation behavior of $\mathrm{TiB}_{\mathrm{x}}$, same thin films as in the preceding paper. Prior to this work, the oxidation properties and behavior of understoichiometric $\mathrm{TiB}_{\mathrm{x}}$ thin films were largely unknown. Herein I show that these films oxidize at a significantly slower rate than their overstoichiometric counterparts. Oxidized $\mathrm{B}$ forms hydroscopic $\mathrm{B}_{2} \mathrm{O}_{3}$, a phase that evaporates in the presence of water vapor by forming acids, which are gaseous at elevated temperatures $\left(+140{ }^{\circ} \mathrm{C}\right)$. The enhanced oxidation and evaporation of B-rich tissue phase in grain boundaries gives rise to an easy oxidation pathway, allowing larger quantities of $\mathrm{O}$ and $\mathrm{H}_{2} \mathrm{O}$ to enter the film, and similarly, for acids ( $\mathrm{g}$ ) to escape the film. The absence of B-rich tissue phase thus reduced the rate of which understoichiometric $\mathrm{TiB}_{\mathrm{x}}$ oxidizes. 
After concluding the $\mathrm{TiB}_{\mathrm{x}}$ papers, $\mathrm{I}$ focused on the material system $\mathrm{Ti}_{\mathrm{x}-1} \mathrm{Al}_{\mathrm{x}} \mathrm{B}_{2-\mathrm{y}}$ in Paper III, titled "Oxidation resistance and mechanical properties of sputterdeposited Tio.9Al0.1 $\mathrm{B}_{2-\mathrm{y}}(y: 0.1-0.7)$ metal boride thin films", where I carried out an investigation on the mechanical properties and oxidation behavior as a function of 1) varying metal ratios with fixed $B$ content and 2) fixed metal ratios and varying $B$ content. A few studies on this system have been done prior to this work, but largely on films with a large amount of $\mathrm{Al}(\sim 20-60 \%)$. Al is known to significantly improve the oxidation resistance in thin films, by forming a protective scale of $\mathrm{Al}_{2} \mathrm{O}_{3}$ on the film surface, passivating oxidation. However, the consequence of larger amounts of $\mathrm{Al}$ in $\mathrm{Ti}_{1-\mathrm{x}} \mathrm{Al}_{\mathrm{x}} \mathrm{B}_{2-\mathrm{y}}$ is a deterioration of the superior mechanical properties otherwise seen in the pure $\mathrm{TiB}_{\mathrm{x}}$ system. In this paper, I show that by controlling, and considerably reducing, both the $\mathrm{Al}$ and the $\mathrm{B}$ content in $\mathrm{Ti}_{1-\mathrm{x}} \mathrm{Al}_{\mathrm{x}} \mathrm{B}_{2-\mathrm{y}}$, the mechanical properties seen in $\mathrm{TiB}_{\mathrm{x}}$ films are retained while acquiring the superior oxidation behavior that characterizes $\mathrm{Al}$ alloyed materials. I proposed that this is due to the reduction of the overall amount of $\mathrm{Al}$ and $\mathrm{B}$ in $\mathrm{Ti}_{1-\mathrm{x}} \mathrm{Al}_{\mathrm{x}} \mathrm{B}_{2-\mathrm{y}}$ thin films which correlates to a reduction of boundary phase. The boundary phase in this material consists of a $\mathrm{Ti}_{1-\mathrm{x}} \mathrm{Al}_{\mathrm{x}} \mathrm{B}_{2-\mathrm{y}}$ tissue phase enriched with either $\mathrm{Al}$ or $\mathrm{B}$, depending on the overall $\mathrm{Al}$ and $\mathrm{B}$ content. $\mathrm{By}$ reducing the $\mathrm{Al}$ and $\mathrm{B}$ content, I essentially deplete the film of its boundary phase therefore improving both the mechanical properties and the oxidation resistance, in line with the findings for $\mathrm{TiB}_{\mathrm{x}}$.

Thereafter, $\mathrm{CrB}_{\mathrm{x}}$ thin films were systematically investigated in Paper IV, titled "Synthesis and Characterization of $\mathrm{CrB}_{\mathbf{x}}$ Thin Films Grown by DC Magnetron Sputtering", to determine compositional, microstructural and texture dependence on deposition pressure and substrate temperature using DCMS synthesis. $\mathrm{CrB}_{\mathrm{x}}$ films' composition shows a relatively modest dependence on temperature with a slight dependence on pressure for samples deposited at a higher temperature. The (001) texture of $\mathrm{CrB}_{\mathrm{x}}$ films was seen in all films, with epitaxial film growth at higher a temperature. Understoichiometric $\mathrm{CrB}_{\mathrm{x}}$ films also appear to contain planar defects of $\mathrm{Cr}$-rich stacking faults in a similar manner as the understoichiometric $\mathrm{TiB}_{\mathrm{x}}$ films. Conversely, excess $\mathrm{B}$ in overstoichiometric $\mathrm{CrB}_{\mathrm{x}}$ films was presented as larger B-rich inclusions, as opposed 
to the formation of a B-rich tissue phase in corresponding synthesis of overstoichiometric $\mathrm{TiB}_{\mathrm{x}}$.

A systematic investigation of thin films grown with HiPIMS was done in Paper V, titled "High-Power Impulse Magnetron Sputter Deposition of TiB $_{\mathbf{x}}$ Thin Films: Effects of Pressure and Growth Temperature", and the films were compared with those grown with DCMS under similar conditions. I show that the HiPIMS waveform, voltage and current pulses, is affected by process pressure and temperature. The peak current in the current pulse is largely unaffected, while the plasma ignition time and current rise time vary with Ar pressure and temperature. The faster plasma response at higher pressure is due to the higher density of ionizable Ar atoms, while the slower plasma ignition and current rise time is attributed to the decrease in gas density. Change in temperature at higher Ar pressures showed less effect on the target voltage pulse than lower pressures. We attribute this to temperature-induced gas rarefaction. We also show that compositional changes in $\mathrm{TiB}_{\mathrm{x}}$ films behave differently at higher and lower pressures, for varying temperature. At lower pressure, the film composition is largely unaffected by the temperature and only shows a slight increase in B:Ti ratio at elevated temperatures. At higher pressure, the effect of temperature is more significant, showing a clear reduction in the $\mathrm{B}$ :Ti ratio with increasing temperature. We explain this with temperature-induced gas density rarefaction. Films deposited by DCMS at lower pressures show no significant change in $\mathrm{B}: \mathrm{Ti}$ ratio, irrespective of temperature. However, at higher pressures, the B:Ti ratio increased with increasing temperature. We explain all results as a function of sputtered-atom ionization probabilities together with gas- and temperature dependent gas-phase scattering. 


\section{OUTLOOK}

In this thesis, much emphasis is put on the compositional control of TM diboride thin films. Obtaining accurate compositions for the films presented in Papers I, II and IV, posed great challenges. ERDA, RBS and XPS techniques each individually has strengths and weaknesses, and together, unfortunately, rarely show consistent results. This is something that needs to be further studied and evaluated, to facilitate accurate and reliable quantification of the film composition, which, in turn, will improve the understanding of the deposition process as well as of the thin films.

One very interesting characteristic of several TM diborides is their inherent line compound nature, resulting in the material favoring the formation of single-phase compounds (all excess material in TM diborides are usually presented as a tissue phase or as inclusions). This naturally leads to significant differences in microstructure, and consequently also properties, depending on the boron to metal ratios. To obtain overand understoichiometric TM diboride films, for various metals, in addition to performing microstructural analysis (XRD, TEM) as well as property characterization, to fully grasp their attributes, is imperative. The attained knowledge can be used for identification of interesting materials characteristics, and for improved control of the materials properties. The challenge here is to have access to high quality microstructural analysis.

To achieve both over- and understoichiometric TM diborides, both HiPIMS and DCMS need to be considered. HiPIMS is a more flexible deposition technique that offers improved control of more deposition parameters. The fundamental understanding of HiPIMS, and how it behaves for deposition of different elements, in particular if they originate from a compound target, needs to be expanded in order to do qualitative research on composition depending properties in materials, such as TM diborides. In Paper V, I show how complicated, yet powerful, HiPIMS can be when using it as a deposition method for $\mathrm{TiB}_{\mathrm{x}}$ films. A weak aspect of HiPIMS, however, is the deposition rate. Using the same average power as DCMS, HiPIMS films often generate films of 
1/3-1/4 of the thickness of the corresponding DCMS films. This is unfortunately also true for industrial scale depositions and a challenge faced several times in this thesis work. The limitation is set by the peak current in the HiPIMS pulse. High peak current leads to arcing, which is devastating for the film's quality. The challenge is to increase the deposition rate of HiPIMS without losing synthesis control and film quality.

In Papers III and IV, the investigation of oxidation properties were made for $\mathrm{TiB}_{\mathrm{x}}$ and $\mathrm{Ti}_{1-\mathrm{x}} \mathrm{Al}_{\mathrm{x}} \mathrm{B}_{2-\mathrm{y}}$ coatings. Up to today, very few studies have been done on the oxidation kinetics of TM diborides in thin film form, in part explained by the unfavorable oxidation kinetics of $\mathrm{B}$ in $\mathrm{TM}$ diborides. I show that through $\mathrm{Al}$ alloying, the poor oxidation resistance can be circumvented. Future work is needed to attempt to incorporate an element resilient to oxidation, similar to $\mathrm{Al}$, without compromising the desirable characteristics of TM diborides, and to push the viability in both low- and high-temperature applications. Another challenge is accurate measurement of the volumetric flow rates of atmospheric gases on the sample's surfaces. This is a variable not included in this thesis's work and is fundamental for more qualitative and controlled oxidation investigations. This is especially important when investigating materials more susceptible to specific gases. In B compounds, the humidity plays a significant role on the rate of evaporation for hydroscopic boron-oxide $\mathrm{B}_{2} \mathrm{O}_{3}$, this in turn affects the overall oxidation rate. Most literature suffers from the same lack of information, which unfortunately reduces the amount of conclusive analysis.

The investigation of the $\mathrm{Ti}_{1-\mathrm{x}} \mathrm{Al}_{\mathrm{x}} \mathrm{B}_{\mathrm{y}-2}$ in Paper IV shows the possibility to investigate attainable compositions of ternary TM diborides using segmented targets, allowing for a fixed compositional with respect to either the Ti:Al ratio or the boron to metal ratio. Many studies today fail to show trends for one changed variable at a time, instead there are often multiple dependencies. Future work to investigate multicomponent systems by narrowing down changes to one parameter at a time is necessary. Investigating a $\mathrm{M}_{\mathbf{1}^{-}}$ $\mathrm{M}_{2}$-B system to determine the effect of (transition-metal and/or metal) $M_{1}: M_{2}$ ratio, while simultaneously varying B:M, can be inconclusive. The challenge with this approach is an inevitable change in microstructure, as displayed in Paper IV. 
Establishing the effect of composition, microstructure and texture on the materials properties, is important for increasing the applicability of the material. 


\section{BIBLIOGRAPHY}

1. B. Albert and H. Hillebrecht, Angewandte Chemie International Edition, 2009, 48, 8640-8668.

2. M. Ade and H. Hillebrecht, Inorganic chemistry, 2015, 54, 6122-6135.

3. G. Akopov, L. E. Pangilinan, R. Mohammadi and R. B. Kaner, APL Materials, 2018, 6, 070901.

4. Y. B. Paderno, Y. M. Goryachev and E. Garf, ELECTRON TECHNOL, 1970, 3, 175-183.

5. M. Takeda, M. Terui, N. Takahashi and N. Ueda, Journal of Solid State Chemistry, 2006, 179, 2823-2826.

6. M. Gürsoy, M. Takeda and B. Albert, Journal of Solid State Chemistry, 2015, 221, 191-195.

7. M. A. Hossain, I. Tanaka, T. Tanaka, A. U. Khan and T. Mori, Journal of Physics and Chemistry of Solids, 2015, 87, 221-227.

8. T. Lundstrom, Pure and Applied Chemistry, 1985, 57, 1383-1390.

9. J. Nagamatsu, N. Nakagawa, T. Muranaka, Y. Zenitani and J. Akimitsu, nature, 2001, 410, 63.

10. R. W. Cumberland, M. B. Weinberger, J. J. Gilman, S. M. Clark, S. H. Tolbert and R. B. Kaner, Journal of the American Chemical Society, 2005, 127, 72647265 .

11. B. Basu, G. Raju and A. Suri, International materials reviews, 2006, 51, 352374.

12. C. Mitterer, Journal of solid state chemistry, 1997, 133, 279-291.

13. C. Mitterer, F. Holler, F. Üstel and D. Heim, Surface and coatings Technology, 2000, 125, 233-239.

14. I. E. Campos-Silva and G. A. Rodriguez-Castro, in Thermochemical surface engineering of steels, Elsevier, 2015, pp. 651-702.

15. N. Kalfagiannis, G. Volonakis, L. Tsetseris and S. Logothetidis, Journal of Physics D: Applied Physics, 2011, 44, 385402.

16. P. Mayrhofer, C. Mitterer, J. Wen, J. Greene and I. Petrov, Applied Physics Letters, 2005, 86, 131909.

17. B. Bakhit, J. Palisaitis, J. Thörnberg, J. Rosen, P. O. Persson, L. Hultman, I. Petrov, J. E. Greene and G. Greczynski, Acta Materialia, 2020, 196, 677-689.

18. M. Bauccio, ASM engineered materials reference book, CRC, 1994.

19. H. Choi, B. Park and J. Lee, Surface and Coatings Technology, 2007, 202, 982986.

20. A. Mockute, J. Palisaitis, N. Nedfors, P. Berastegui, E. Broitman, B. Alling, L.-Å. Näslund, L. Hultman, J. Patscheider and U. Jansson, Thin Solid Films, 2019, 669, 181-187.

21. N. Nedfors, S. Mráz, J. Palisaitis, P. O. Persson, H. Lind, S. Kolozsvari, J. M. Schneider and J. Rosen, Surface and Coatings Technology, 2019, 364, 89-98.

22. L. Pauling, Journal of the american Chemical Society, 1931, 53, 3225-3237.

23. N. P. Bansal, Handbook of ceramic composites, Springer Science \& Business Media, 2006. 
24. L. Bsenko and T. Lundström, Journal of the Less Common Metals, 1974, 34, 273-278.

25. W. G. Fahrenholtz, E. J. Wuchina, W. E. Lee and Y. Zhou, Ultra-high temperature ceramics: materials for extreme environment applications, John Wiley \& Sons, 2014.

26. J. Cotton, Advanced materials \& processes, 2010, 168, 26-28.

27. W. G. Fahrenholtz, G. E. Hilmas, I. G. Talmy and J. A. Zaykoski, Journal of the American Ceramic Society, 2007, 90, 1347-1364.

28. J. Justin and A. Jankowiak, 2011.

29. C. Tallon and G. V. Franks, Ultra-high temperature ceramics: materials for extreme environment applications, 2014, 83-111.

30. D. Demirskyi, I. Solodkyi, T. Nishimura and O. O. Vasylkiv, Journal of the American Ceramic Society, 2019, 102, 4259-4271.

31. J. Thörnberg, J. Palisaitis, N. Hellgren, F. F. Klimashin, N. Ghafoor, I. Zhirkov, C. Azina, J.-L. Battaglia, A. Kusiak and M. A. Sortica, Surface and Coatings Technology, 2020, 126537.

32. P. H. Mayrhofer, C. Mitterer, L. Hultman and H. Clemens, Progress in materials science, 2006, 51, 1032-1114.

33. S. PalDey and S. Deevi, Materials Science and Engineering: A, 2003, 342, 5879.

34. E. Johansson, A. Ektarawong, J. Rosen and B. Alling, Journal of Applied Physics, 2020, 128, 235101.

35. V. Moraes, H. Riedl, C. Fuger, P. Polcik, H. Bolvardi, D. Holec and P. Mayrhofer, Scientific reports, 2018, 8, 1-9.

36. V. Moraes, C. Fuger, V. Paneta, D. Primetzhofer, P. Polcik, H. Bolvardi, M. Arndt, H. Riedl and P. Mayrhofer, Scripta Materialia, 2018, 155, 5-10.

37. B. Bakhit, D. L. Engberg, J. Lu, J. Rosen, H. Högberg, L. Hultman, I. Petrov, J. E. Greene and G. Greczynski, Journal of Vacuum Science \& Technology A: Vacuum, Surfaces, and Films, 2019, 37, 031506.

38. N. Cabrera and N. F. Mott, Reports on progress in physics, 1949, 12, 163-184.

39. R. E. Smallman, Modern physical metallurgy, Elsevier, 2016.

40. N. Birks, G. H. Meier and F. S. Pettit, Introduction to the high temperature oxidation of metals, Cambridge University Press, 2006.

41. A. Kulpa and T. Troczynski, Journal of the American Ceramic Society, 1996, 79, 518-520.

42. T. Parthasarathy, R. Rapp, M. Opeka and R. Kerans, Acta Materialia, 2007, 55, 5999-6010.

43. W. G. Fahrenholtz and G. E. Hilmas, Scripta Materialia, 2017, 129, 94-99.

44. M. Barandika, J. Echeberria, J. Sanchez and F. Castro, Journal of Materials Chemistry, 1998, 8, 1851-1857.

45. V. Voitovich, V. Lavrenko and V. Adejev, Oxidation of metals, 1994, 42, 145161.

46. R. David, CRC Handbook of Chemistry and Physics 81st Edition: A Readyreference Book of Chemical and Physical Data, CRC press, 2000.

47. C. Huber, S. Setoodeh Jahromy, C. Jordan, M. Schreiner, M. Harasek, A. Werner and F. Winter, Energies, 2019, 12, 1086. 
48. R. Viswanathan, T. L. Narasimhan and S. Nalini, The Journal of Physical Chemistry B, 2009, 113, 8362-8368.

49. M. Mikula, B. Grančič, T. Roch, T. Plecenik, I. Vávra, E. Dobročka, A. Šatka, V. Buršíková, M. Držík and M. Zahoran, Vacuum, 2011, 85, 866-870.

50. F. Lofaj, T. Moskalewicz, G. Cempura, M. Mikula, J. Dusza and A. CzyrskaFilemonowicz, Journal of the European Ceramic Society, 2013, 33, 23472353.

51. M. Berger, M. Larsson and S. Hogmark, Surface and Coatings Technology, 2000, 124, 253-261.

52. D. R. Lide, CRC handbook of chemistry and physics, CRC press, 2004.

53. R. G. Munro, Journal of Research of the National Institute of Standards and Technology, 2000, 105, 709.

54. I. Korobov, G. Kalinnikov, A. Ivanov, N. Dremova, R. Andrievski and S. Shilkin, Protection of Metals and Physical Chemistry of Surfaces, 2016, 52, 618-621.

55. A. Dranenko, V. Lavrenko and V. Talash, Powder Metallurgy and Metal Ceramics, 2010, 49, 174-178.

56. G. Nelson and J. Borders, Journal of Nuclear Materials, 1980, 93, 640-644.

57. P. Vajeeston, P. Ravindran, C. Ravi and R. Asokamani, Physical Review B, 2001, 63, 045115.

58. I. Zyganitidis, N. Kalfagiannis and S. Logothetidis, Materials Science and Engineering: B, 2009, 165, 198-201.

59. M. N. Polyakov, M. Morstein, X. Maeder, T. Nelis, D. Lundin, J. Wehrs, J. Best, T. Edwards, M. Döbeli and J. Michler, Surface and Coatings Technology, 2019, 368, 88-96.

60. S. Mollica, D. Sood, P. Evans, J. Noorman, N. Dytlewski, N. Brack, P. Pigram and K. Latham, Surface and Coatings Technology, 2004, 177, 185-197.

61. M. Emiliani, Materials Science and Engineering: A, 1993, 172, 111-124.

62. M. Bauccio, ASM metals reference book, ASM international, 1993.

63. K. Dahm, L. Jordan, J. Haase and P. Dearnley, Surface and Coatings Technology, 1998, 108, 413-418.

64. S. Zhang, Z. Wang, P. Guo, P. Ke, M. Odén and A. Wang, Surface and Coatings Technology, 2017, 322, 134-140.

65. N. Wallbridge, D. Dowson, E. Roberts and K. Ludema, 1983.

66. B. Matthes, E. Broszeit, J. Aromaa, H. Ronkainen, S.-P. Hannula, A. Leyland and A. Matthews, Surface and Coatings Technology, 1991, 49, 489-495.

67. J. A. Thornton, Annual review of materials science, 1977, 7, 239-260.

68. P. Barna and M. Adamik, Thin solid films, 1998, 317, 27-33.

69. Y. Kajikawa, S. Noda and H. Komiyama, Journal of Vacuum Science \& Technology A: Vacuum, Surfaces, and Films, 2003, 21, 1943-1954.

70. M. Zhou, M. Nose, Y. Makino and K. Nogi, Thin Solid Films, 2000, 359, 165170.

71. N. Nedfors, D. Primetzhofer, L. Wang, J. Lu, L. Hultman and U. Jansson, Surface and Coatings Technology, 2015, 266, 167-176.

72. I. Petrov, A. Hall, A. B. Mei, N. Nedfors, I. Zhirkov, J. Rosen, A. Reed, B. Howe, G. Greczynski and J. Birch, Journal of Vacuum Science \& Technology A: Vacuum, Surfaces, and Films, 2017, 35, 050601. 
73. N. Hellgren, J. Thörnberg, I. Zhirkov, M. A. Sortica, I. Petrov, J. E. Greene, L. Hultman and J. Rosen, Vacuum, 2019, 169, 108884.

74. J. Neidhardt, S. Mráz, J. M. Schneider, E. Strub, W. Bohne, B. Liedke, W. Möller and C. Mitterer, Journal of applied physics, 2008, 104, 063304.

75. J. Thörnberg, J. Palisaitis, N. Hellgren, F. F. Klimashin, N. Ghafoor, I. Zhirkov, C. Azina, J.-L. Battaglia, A. Kusiak and M. A. Sorica, Surface and Coatings Technology, 2020, 126537.

76. J. Palisaitis, M. Dahlqvist, A. J. Hall, J. Thörnberg, I. Persson, N. Nedfors, L. Hultman, J. E. Greene, I. Petrov and J. Rosen, Acta Materialia, 2020, 116510.

77. A. C. Jones and M. L. Hitchman, Chemical vapour deposition: precursors, processes and applications, Royal society of chemistry, 2009.

78. P. Eklund, M. Beckers, U. Jansson, H. Högberg and L. Hultman, Thin Solid Films, 2010, 518, 1851-1878.

79. W. Gill and E. Kay, Review of Scientific Instruments, 1965, 36, 277-282.

80. G. W. Neudeck and R. F. Pierret, Modular Series on Solid State Devices, 2002 , 5.

81. P. Sigmund, Nuclear Instruments and Methods in Physics Research Section B: Beam Interactions with Materials and Atoms, 1987, 27, 1-20.

82. W. R. Grove, Philosophical Transactions of the Royal Society of London, 1852, 87-101.

83. I. Langmuir, Science, 1923, 58, 290-291.

84. A. Pargellis, Journal of Vacuum Science \& Technology A: Vacuum, Surfaces, and Films, 1989, 7, 27-30.

85. F. M. Penning, physica, 1936, 3, 873-894.

86. V. Kouznetsov, K. Macak, J. M. Schneider, U. Helmersson and I. Petrov, Surface and coatings technology, 1999, 122, 290-293.

87. B. Bakhit, I. Petrov, J. E. Greene, L. Hultman, J. Rosén and G. Greczynski, Journal of Vacuum Science \& Technology A: Vacuum, Surfaces, and Films, 2018, 36, 030604.

88. K. Sarakinos, J. Alami and S. Konstantinidis, Surface and Coatings Technology, 2010, 204, 1661-1684.

89. U. Helmersson, M. Lattemann, J. Bohlmark, A. P. Ehiasarian and J. T. Gudmundsson, Thin solid films, 2006, 513, 1-24.

90. W. Leroy, S. Mahieu, D. Depla and A. Ehiasarian, Journal of Vacuum Science \& Technology A: Vacuum, Surfaces, and Films, 2010, 28, 108-111.

91. J. T. Gudmundsson, J. Alami and U. Helmersson, Surface and Coatings Technology, 2002, 161, 249-256.

92. J. Alami, P. Eklund, J. M. Andersson, M. Lattemann, E. Wallin, J. Bohlmark, P. Persson and U. Helmersson, Thin Solid Films, 2007, 515, 3434-3438.

93. S. Konstantinidis, A. Hemberg, J. Dauchot and M. Hecq, Journal of Vacuum Science \& Technology B: Microelectronics and Nanometer Structures Processing, Measurement, and Phenomena, 2007, 25, L19-L21.

94. J. Alami, K. Sarakinos, F. Uslu and M. Wuttig, Journal of Physics D: Applied Physics, 2008, 42, 015304.

95. A. Ehiasarian, P. E. Hovsepian, L. Hultman and U. Helmersson, Thin solid films, 2004, 457, 270-277. 
96. J. Alami, P. Eklund, J. Emmerlich, O. Wilhelmsson, U. Jansson, H. Högberg, L. Hultman and U. Helmersson, Thin Solid Films, 2006, 515, 1731-1736.

97. S. Konstantinidis, J. Dauchot and M. Hecq, Thin Solid Films, 2006, 515, 11821186.

98. J. Alami, K. Sarakinos, F. Uslu, C. Klever, J. Dukwen and M. Wuttig, Journal of Physics D: Applied Physics, 2009, 42, 115204.

99. J. Paulitsch, P. Mayrhofer, C. Mitterer, W. Münz and M. Schenkel, 2007.

100. V. Sittinger, F. Ruske, W. Werner, C. Jacobs, B. Szyszka and D. Christie, Thin Solid Films, 2008, 516, 5847-5859.

101. K. Sarakinos, J. Wördenweber, F. Uslu, P. Schulz, J. Alami and M. Wuttig, Surface and Coatings Technology, 2008, 202, 2323-2327.

102. M. Birkholz, Thin film analysis by X-ray scattering, John Wiley \& Sons, 2006.

103. V. H. Nowotny, Progress in Solid State Chemistry, 1971, 5, 27-70.

104. P. E. Flewitt and R. K. Wild, Physical methods for materials characterisation, CRC Press, 2017.

105. L. d. Broglie, The London, Edinburgh, and Dublin Philosophical Magazine and Journal of Science, 1924, 47, 446-458.

106. S. Hillyard, R. F. Loane and J. Silcox, Ultramicroscopy, 1993, 49, 14-25.

107. K. Kimoto, K. Ishizuka and Y. Matsui, Micron, 2008, 39, 653-657.

108. P. Voyles, J. Grazul and D. Muller, Ultramicroscopy, 2003, 96, 251-273.

109. P. Van der Heide, An Introduction to Principles and Practices, 2011.

110. G. Greczynski, D. Primetzhofer and L. Hultman, Applied Surface Science, 2018, 436, 102-110.

111. E. Lewin, J. Counsell and J. Patscheider, Applied Surface Science, 2018, 442, 487-500.

112. Y. Zhang, H. J. Whitlow, T. Winzell, I. F. Bubb, T. Sajavaara, K. Arstila and J. Keinonen, Nuclear Instruments and Methods in Physics Research Section B: Beam Interactions with Materials and Atoms, 1999, 149, 477-489.

113. P. Ström, P. Petersson, M. Rubel and G. Possnert, Review of Scientific Instruments, 2016, 87, 103303.

114. E. Arslan, Y. Totik, A. Celik and I. Efeoglu, Surface Engineering, 2010, 26, 567-570.

115. R. Lohmann, E. Österschulze, K. Thoma, H. Gärtner, W. Herr, B. Matthes, E. Broszeit and K.-H. Kloos, Materials Science and Engineering: A, 1991, 139, 259-263.

116. T. F. Zhang, B. Gan, S.-m. Park, Q. M. Wang and K. H. Kim, Surface and Coatings Technology, 2014, 253, 115-122.

117. W. C. Oliver and G. M. Pharr, Journal of materials research, 1992, 7, 15641583.

118. S. Dodd, M. Cankurtaran, G. Saunders and B. James, Journal of materials science, 2001, 36, 3989-3996.

119. W. Gust, A. Holt and E. Royce, Journal of Applied Physics, 1973, 44, 550-560.

120. I. R. Shein and A. L. Ivanovskii, Journal of Physics: Condensed Matter, 2008, 20, 415218.

121. D. Wiley, W. Manning and O. Hunter Jr, Journal of the Less Common Metals, 1969, 18, 149-157.

122. A. C. Fischer-Cripps, Surface and coatings technology, 2006, 200, 4153-4165. 
123. T. Guillemet, A. Kusiak, L. Fan, J.-M. Heintz, N. Chandra, Y. Zhou, J.-F. Silvain, Y. Lu and J.-L. Battaglia, ACS applied materials \& interfaces, 2014, 6, 2095-2102.

124. A. Kusiak, J. Martan, J.-L. Battaglia and R. Daniel, Thermochimica acta, 2013, 556, $1-5$. 


\section{Papers}

The papers associated with this thesis have been removed for copyright reasons. For more details about these see:

http://urn.kb.se/resolve?urn=urn:nbn:se:liu:diva-172716 


\section{FACULTY OF SCIENCE AND ENGINEERING}

Linkóping Studies in Science and Technology/ Dissertation No 2117,2021 Department of Physics, Chemistry and Biology (IFM)

Linkoping University

SE-581 83 Linkoping, Sweden

WwW liuse 